Review

\title{
Alpha-Synuclein and Cognitive Decline in Parkinson Disease
}

\author{
Tian-Sin Fan ${ }^{1}$, Sam Chi-Hao Liu ${ }^{2}$ and Ruey-Meei $\mathrm{Wu}^{2, *}$ (1) \\ 1 Department of Neurology, National Taiwan University Hospital Hsin-Chu Branch, Hsinchu City 300, Taiwan; \\ tsfan119@ntu.edu.tw \\ 2 Department of Neurology, National Taiwan University Hospital, College of Medicine, National Taiwan \\ University, Taipei City 100, Taiwan; samntuh@ntuh.gov.tw \\ * Correspondence: robinwu@ntu.edu.tw; Tel.: +886-2-2312-3456 (ext. 65337)
}

check for

updates

Citation: Fan, T.-S.; Liu, S.C.-H.; Wu, R.-M. Alpha-Synuclein and Cognitive Decline in Parkinson Disease. Life 2021, 11, 1239. https://doi.org/ 10.3390/life11111239

Academic Editors: Emanuela Colla and Jessica Grigoletto

Received: 12 October 2021

Accepted: 12 November 2021

Published: 16 November 2021

Publisher's Note: MDPI stays neutral with regard to jurisdictional claims in published maps and institutional affiliations.

Copyright: (c) 2021 by the authors. Licensee MDPI, Basel, Switzerland. This article is an open access article distributed under the terms and conditions of the Creative Commons Attribution (CC BY) license (https:/ / creativecommons.org/licenses/by/ $4.0 /)$.

\begin{abstract}
Parkinson disease (PD) is the second most common neurodegenerative disorder in elderly people. It is characterized by the aggregation of misfolded alpha-synuclein throughout the nervous system. Aside from cardinal motor symptoms, cognitive impairment is one of the most disabling nonmotor symptoms that occurs during the progression of the disease. The accumulation and spreading of alpha-synuclein pathology from the brainstem to limbic and neocortical structures is correlated with emerging cognitive decline in PD. This review summarizes the genetic and pathophysiologic relationship between alpha-synuclein and cognitive impairment in $\mathrm{PD}$, together with potential areas of biomarker advancement.
\end{abstract}

Keywords: Parkinson disease; alpha-synuclein; cognition; dementia; non-motor symptom; Lewy body; genetic; SNCA; neurodegeneration; biomarker

\section{Introduction}

Parkinson disease (PD) is the second most common neurodegenerative disease. Pathologically, it is characterized by dopaminergic neuronal loss in the substantia nigra pars compacta $(\mathrm{SNpc})$, and the proteinaceous aggregates composed predominantly of alphasynuclein $(\alpha S)$, known as Lewy bodies, within neuronal cell bodies [1]. PD is now recognized as a multisystem disorder with the cardinal motor symptoms bradykinesia, rigidity, resting tremor, postural instability, and various non-motor symptoms (NMS) including anxiety, depression, sleep disorders, autonomic dysfunction, and cognitive impairment [2,3].

Cognitive decline is among the most common and debilitating NMS. There is growing evidence that most patients with PD eventually develop cognitive deficits over the progression of the disease [4-7]. Mild cognitive impairment in PD (PD-MCI) refers to the transitional state between normal cognition and overt dementia [8]. A study reported the point prevalence of PD-MCI to be around 20-30\% [4]. In comparison with age-matched normal control groups, people with PD have an almost six-fold increased risk of developing dementia (PD dementia, PDD), in which they exhibit cognitive decline, especially in executive function, attention, visuospatial domains, and memory $[9,10]$. The long-term cumulative prevalence of dementia is $75 \%$ for PD patients who live for more than 10 years after disease onset [11,12].

The progressive nature of the cognitive impairment may be a reflection of the spreading pathology that underlies PD. The pathophysiological mechanisms of PDD are being elucidated, but likely include the direct cortical involvement of Lewy pathology. Good evidence from postmortem studies shows a correlation between limbic and cortical spread of Lewy pathology in PDD [13-17]. In our daily practice, the progression of motor and non-motor symptoms in PD varies significantly. PD patients who maintain good motor function for years can develop a rapid deterioration in quality of life and reduced life expectancy as cognitive function declines $[18,19]$. Treatment to halt the progression of cognitive impairment in PD is urgently needed. 
In this review, we focus on why PD patients eventually develop cognitive decline and the presumed role of $\alpha S$, including the contribution of genetics, $\alpha S$ protein-protein interaction, and $\alpha \mathrm{S}$ cell-to-cell propagation. Finally, we summarize recent efforts toward the identification of biomarkers for patients with PDD.

\section{Alpha-Synuclein, Lewy Body, and Dementia}

Synucleinopathy underlies a wide spectrum of clinical syndromes, including PD, PDD, dementia with Lewy bodies (DLB), multiple system atrophy (MSA), and pure autonomic failure (PAF). In order to provide diagnostic accuracy and define patients likely to respond to disease modifying therapy, a hierarchical classification has been proposed based on the underlying pathological protein deposition $(\alpha S)$, cellular inclusions (Lewy bodies or glial cytoplasmic inclusion, GCI), and clinical phenotypes (parkinsonism, dementia, or autonomic failure) [20]. The pathological hallmark of MSA is the presence of GCI in oligodendrocytes. In PAF, there is predominantly a peripheral deposition of Lewy bodies in autonomic ganglia and nerve fibers without evidence of central nervous system (CNS) dysfunction other than rapid eye movement sleep behavior disorder (REMSBD). Patients with PAF have an increased risk of developing PD, DLB, or MSA later in life [21], possibly indicating a pathophysiological disease continuum. REMSBD is a well-recognized prodrome of synucleinopathies [22], as well as a risk factor of developing cognitive impairment [23].

The Lewy body is a hallmark pathological feature in familial PD, sporadic PD, and other Lewy body diseases (LBD), including PDD and DLB [24-26]. They share $\alpha$ S aggregation and cellular inclusions of Lewy bodies as their key pathogenic events [27,28]. PDD and DLB are together known as Lewy body dementia, and the timing of dementia relative to the clinical features of parkinsonism is the major clinical distinction between PDD and DLB. PDD describes dementia that occurs at least one year after the onset of well-established PD (the one-year rule) [29], whereas in DLB, dementia essentially precedes or co-occurs with parkinsonism and has core features of cognitive fluctuation and visual hallucination [30]. Although PDD and DLB share many overlapping clinical and pathological features, there are major differences. Histopathologically, limbic and neocortical involvement of Lewy pathology are both found in PDD and DLB. However, there is a higher burden of neocortical and limbic LBs, more prominent cortical atrophy, and a higher prevalence of coincident Alzheimer's disease (AD) pathology in DLB compared with PDD [31,32]. The propensity for LB propagation by seeding may differ between PDD and DLB as well [33]. On the other hand, at PDD's early stage, it shares a similar $\alpha$ S pathology with PD. Clinically, DLB does not begin with PD or PDD. DLB and PDD also differ in cognitive profiles. Memory and language impairments progress faster in DLB, whereas executive dysfunction progresses more quickly in PDD [34]. Controversy still exists as to whether PDD and DLB should be considered as separate disease entities, or as two ends of the LBD spectrum beginning at the Lewy pathology end with incidental Lewy body disease, through to PD, PDD, and DLB with AD at the amyloid pathology end. There is emerging agreement in clinical trials and research settings that PDD and DLB should be distinguished as two syndromes.

Another emerging concept connecting pathophysiology and cognitive function in neurodegenerative diseases is oscillopathies, which refer to conditions characterized by the abnormal synchronization of synaptic activity [35]. Accumulation of $\alpha \mathrm{S}$ can alter synaptic structure and function, in turn impairing the physiological transmission through the cortico-basal ganglia-thalamic circuits, accounting for abnormalities in motor and cognitive function. Mitochondrial dysfunction is one of the putative mechanisms in many neurodegenerative disorders. The generation of neuronal oscillations highly relies on mitochondrial energy provision. Distinct patterns of brain oscillations may correlate with clinical symptoms and network impairment secondary to physiopathological changes [36].

\section{Physiological Function and Potential Toxicity of Alpha-Synuclein}

Alpha-synuclein $(\alpha S)$ is a 140-amino-acid protein localized in presynaptic nerve terminals [37]. It has three domains with distinct biochemical properties corresponding to 
the amino acid composition (Figure 1). The first 60 residues are known as the N-terminal domain; this region demonstrates $\alpha$-helical propensity and an amphipathic membrane binding ability [38]. The non-amyloid $\beta$-component of plaque (NAC) domain comprises residues 61-95; this region is highly amyloidogenic and responsible for protofibril and fibril formation and aggregation [39]. The carboxyl-terminal (C-terminal) domain, composed of residues 96-140, is the segment where major phosphorylation and truncation occurs. The C-terminal domain of $\alpha \mathrm{S}$ limits pathologic misfolding and aggregation due to its structural factors. The negatively charged C-terminal domain works as a self-chaperone to prevent $\alpha S$ fibrillation by interaction with the NAC region [40]. Loss of acidic C-terminal residues through truncation promotes fibril formation [41]. The complete physiological function of $\alpha \mathrm{S}$ remains unknown, though it is well established that $\alpha \mathrm{S}$ is involved in various neurophysiological processes, including synaptic vesicle recycling, neurotransmission, and synaptic plasticity [42-45].

A

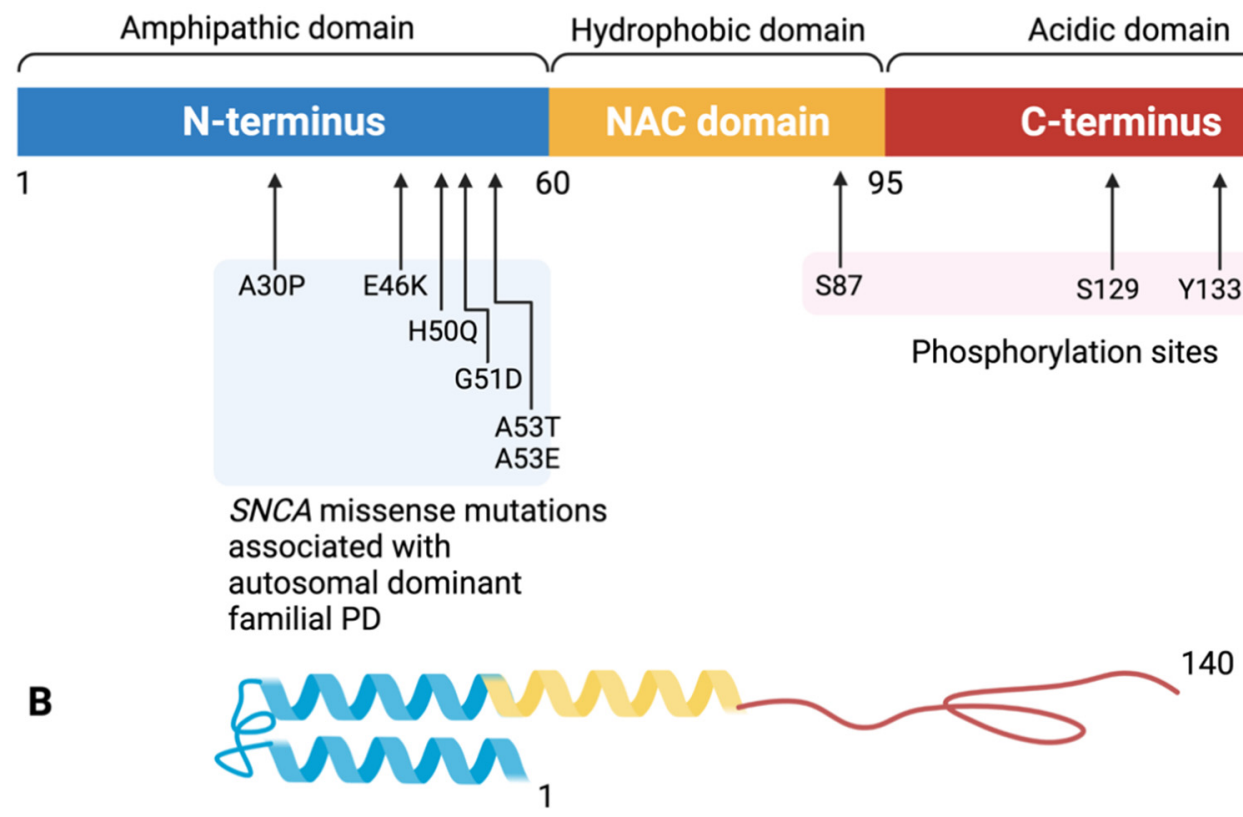

Figure 1. The structure of the alpha-synuclein monomer. (A) Schematic depiction of alpha-synuclein structure. The amino acid residues delimiting the N-terminus, NAC region, and C-terminus as well as those that are sites of known mutations are labeled. The 140-amino-acid protein can be divided into three distinct domains. The N-terminal amphipathic domain (in blue) contains the amino acid residues affected by the main alpha-synuclein gene mutations (A30P, E46K, H50Q, G51D, A53T, A53E) associated with autosomal dominant Parkinson disease. The N-terminal region has a helical folding propensity and is responsible for membrane binding. The hydrophobic non-amyloid $\beta$-component of plaque (NAC) domain (in yellow) is responsible for promoting aggregation. The C-terminal domain (in red) forms an acidic tail containing the main phosphorylation site at Ser129. The C-terminal domain modulates alpha-synuclein aggregation. (B) Tertiary structure of the $\alpha$-synuclein monomer. Created with BioRender.com (accessed on 12 October 2021).

$\alpha \mathrm{S}$ is normally a soluble protein, but it can aggregate to form insoluble fibrils which, in association with other molecules such as ubiquitin, neurofilament protein, alpha B crystallin, organelles, and lipid membranes, form Lewy bodies [46,47]. $\alpha \mathrm{S}$ can exist in the neuron in a monomeric, oligomeric, and soluble protofibrillary state [48]. Monomeric $\alpha S$ is highly dynamic and can populate a large number of different conformational or assembly states $[49,50]$. In synucleinopathies, the formation of the distinct $\alpha \mathrm{S}$ species is determined by the nature of the self-assembly processes, which is influenced by many factors including the alpha synuclein gene (HGNC approved symbol SNCA) mutation or multiplication, epigenetic regulation, post-translational modification, micro-environments, etc. [51,52]. The distinct forms of the $\alpha \mathrm{S}$ protein stack aggregates in neurons, nerve fibers, or glial 
cells at different rates, and can lead to mixed fibrillar polymorphs (species) with different intermolecular interactions, surface characteristics, and pathological consequences [53-55]. However, the precise connection between $\alpha S$ cluster structure and toxicity remains a subject of intense and controversial discussion [53]. We will summarize the literature in the following paragraphs.

Both the oligomeric and fibrillar forms of $\alpha \mathrm{S}$ are toxic to cells, but whether $\alpha S$ oligomers or fibrils are more toxic remains a subject of debate [53]. Growing experimental evidence suggests that specific oligomeric species are the most cytotoxic forms of $\alpha \mathrm{S}$ and play a key role in disease [56-58]. On the other hand, $\alpha S$ fibrils have also been reported to be toxic and their toxicity has been associated with membrane perturbation [59-61]. While oligomers are possibly implicated in the collapse of neuronal homeostasis, the fibrillar state(s) appears to be the most efficient at propagating itself both in vitro and in vivo. While $\alpha S$ oligomers possess toxic properties and are more robust than fibrils, there is no convincing evidence that they can spread in vivo rather than be formed as a collateral effect of the overall aggregation process [62]. In fact, there is no evidence that non-fibrillar oligomers can propagate in a manner similar to that of fibrils [53]. The $\alpha \mathrm{S}$ fibrils can continue to aggregate in association with other proteins such as ubiquitin, neurofilament protein, and alpha B crystallin and form Lewy body-like inclusions $[63,64]$. The mechanistic relationship between oligomers and fibrils remains to be clarified, both in terms of oligomer assembly into fibrils and the potential dissolution of fibrils into oligomers [53].

$\alpha \mathrm{S}$ clusters (oligomers and fibrils) can harm cells through various mechanisms, presumably by interacting with other biomolecules and organelles [65]. For example, it has been proposed that $\alpha \mathrm{S}$ could interact with synaptic vesicles and synaptic proteins such as phospholipase D2 [66], various members of the family of RAB small GTPases [67], and SNARE complexes $[54,68] . \alpha$ S neurotoxicants can be classified as various channel inhibitors, receptor inhibitors, receptor agonists, synaptic vesicle inhibitors, and many more [51]. The toxicity of $\alpha \mathrm{S}$ fibrils and oligomers is in part the consequence of changing the characteristics of lipid membranes. They affect, for example, membrane permeabilization and the formation of pore-like structures [69-72], lipid diffusion and packaging [73], synaptic vesicle fusion pore size [74], and membrane curvature [75]. The possible targets of $\alpha \mathrm{S}$ include synaptic vesicles [76], endoplasmic reticulum (ER)-Golgi transport [77,78], mitochondria [79-81], and lysosomes and other proteolytic machinery [82-84]. The general principle is that multiple systems can be affected by $\alpha \mathrm{S}$ clusters and, if they have a common attribute, they are likely to be lipid membranes [85].

The detrimental effects of $\alpha S$ continue to grow as $\alpha S$ fibrils start to form LBs. The exact mechanisms that promote the aggregation of $\alpha S$ into LBs and what role aggregation plays in pathogenesis remain to be clarified. A time-dependent shift in the morphology and localization of $\alpha S$ pathology from fibrils to cell body inclusions has been demonstrated. The initial aggregation of $\alpha S$ likely starts in presynaptic terminals and accumulates in axons. After reaching the neuronal cell body, $\alpha \mathrm{S}$ aggregates recruit more $\alpha \mathrm{S}$ monomers, undergo posttranslational modifications, and interact with other cellular components to form mature LBs. LB formation and maturation can cause mitochondrial disassembly, mitophagy, mitochondrial depolarization, and synaptic dysfunction that result in progressive neurodegeneration [63]. These findings also support the well-established concept that mitochondrial accumulation of $\alpha \mathrm{S}$ is associated with impaired complex-I-dependent respiration, decreased mitochondrial membrane potential, and increased levels of reactive oxygen species [86,87].

Recent evidence supports a prion-like mechanism of $\alpha \mathrm{S}$ aggregation and spread, whereby introduction of exogenous $\alpha$ S pre-formed fibrils causes endogenous $\alpha S$ to progressively adopt an insoluble, aggregated conformation [88,89]. PD patient-derived $\alpha S$ aggregates can also be taken up by neurons and astrocytes and induce different endogenous responses in the two cell types, leading to neuronal death [90]. However, the exact mechanism of the spreading of $\alpha \mathrm{S}$ fibrils remains a subject of intense discussion. Some 
possible pathways may include trans-synaptic transmission, direct membrane penetration, exocytosis and endocytosis, extracellular vesicles (EVs), and tunneling nanotubes [91-96].

To sum up, the neurotoxicity of $\alpha \mathrm{S}$ aggregates and LB formation can lead to (1) the disintegration of synapses [97-100], (2) mitochondrial dysfunction, (3) membrane perturbation and dysfunction [101-103], (4) $\alpha$ S-induced neuroinflammation via microglial and astrocyte activation [104], and (5) prion-like propagation between neurons. It is also worth noting that the effects of the soluble (normal) form of $\alpha S$ have largely been overlooked, and thus it remains unclear whether the toxicity arises from the accumulation of abnormal $\alpha S$ or the depletion of the soluble (normal) $\alpha \mathrm{S}$.

\section{Parkinson Disease and Cognitive Decline: Genetic Contribution, Alpha-Synuclein Propagation, and Protein-Protein Interaction}

As mentioned above, $\alpha \mathrm{S}$ aggregation in certain brain regions correlates with cognitive decline in patients with PD. At PDD's early stage, it shares a similar $\alpha$ S pathology with PD. However, the risk of developing into progressive cognitive decline increases over time as the global burden of $\alpha S$ pathology increases. The progression of PDD is associated with the $\alpha S$ propagation. The relationship between $\alpha S$ burden and PDD is summarized in Figure 2 . In this section, we will discuss the factors contributing to cognitive impairment in PDD. These include genetic causes, $\alpha \mathrm{S}$ propagation, and protein-protein interaction.

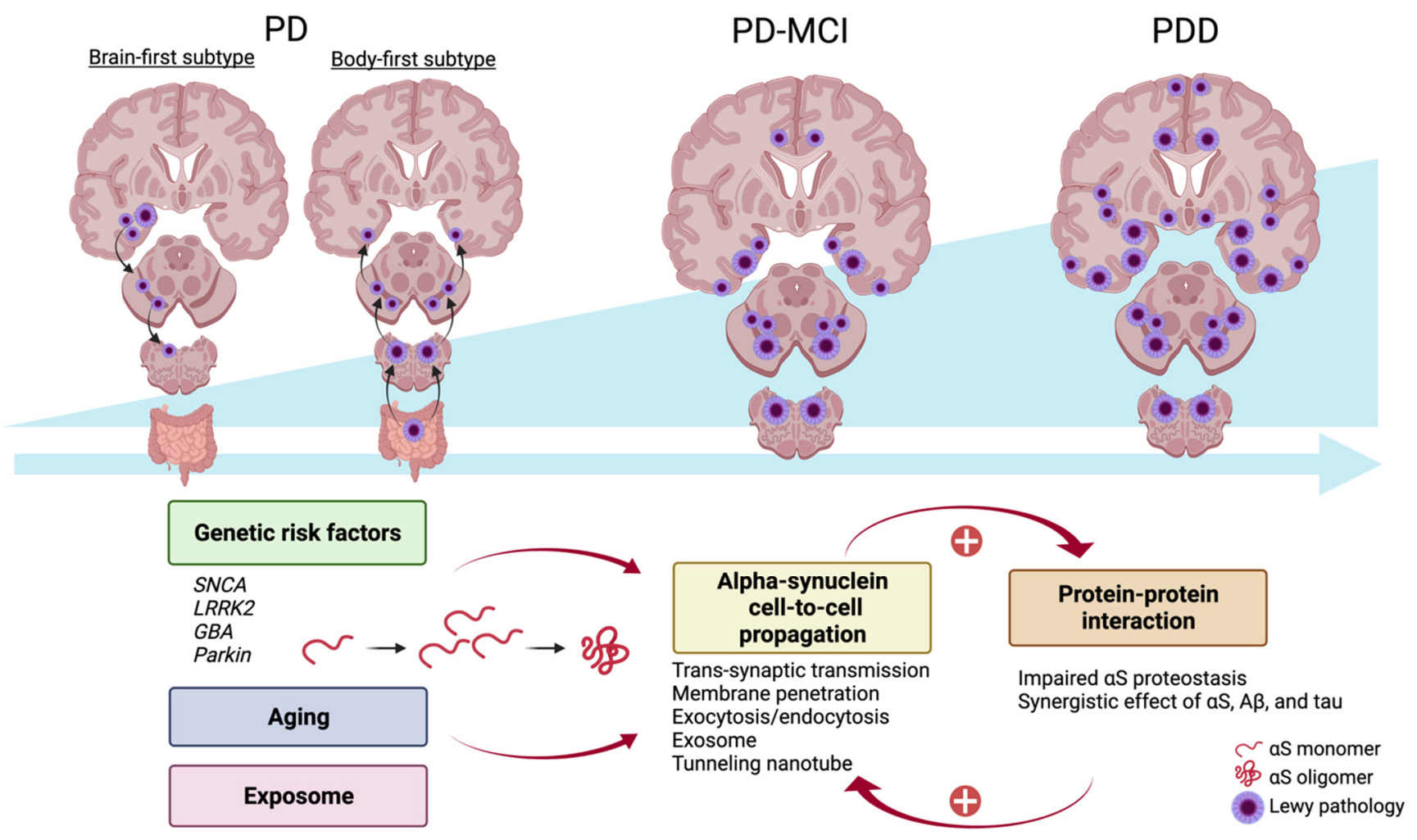

Figure 2. Alpha-synuclein propagation and Parkinson disease dementia. In the early stage of Parkinson disease, the initial alpha-synuclein $(\alpha S)$ pathology originates in the enteric nervous system and spreads to the CNS via the bilateral vagal innervation (body-first subtype) or originates in the unilateral amygdala and spreads to predominantly the ipsilateral hemisphere (brain-first subtype). When the global burden of $\alpha \mathrm{S}$ pathology increases with time, indicated by the blue arrow to the right side and the right triangle under the brain figures, patients with Parkinson disease may develop dementia. Genetic mutation, aging, and the exposome - an integrated function of exposure-contribute to an increased burden of $\alpha \mathrm{S}$ and consequent fibrillation. $\alpha \mathrm{S}$ can spread from cell to cell and interact with both biological proteins and pathogenic proteins such as $A \beta$ and tau. The vicious cycle between $\alpha$ S propagation and dysregulation of protein-protein interaction further enhances neurodegeneration. $A \beta$, Amyloid- $\beta ; \alpha S$, alpha-synuclein; $C N S$, central nervous system. Created with BioRender.com (accessed on 12 October 2021). 


\subsection{Genetic Contribution}

\subsubsection{PD-Related Genes}

\section{- $\quad$ SNCA}

The vast majority of PD cases are sporadic, but multiplications of and missense mutations in SNCA, the gene encoding $\alpha S$, have been associated with familial forms of PD. Mutations in the SNCA gene impose significant risks of developing dementia. SNCA point mutations (A53T, E46K, H50Q, G51D, A53E, and A53V) and SNCA triplication are associated with earlier disease onset with faster disease progression and dementia $[105,106]$. Cortical Lewy pathology is very common with all SNCA mutations. In patients with the SNCA E46K mutation (E46K-SNCA), there is aggressive and widespread LB deposition across the peripheral nervous system (PNS) and CNS, with early non-motor features, small fiber denervation, severe parkinsonism, and dementia [107,108]. Postmortem brain examinations in patients with the SNCA G51D mutation (G51D-SNCA) show significant neuronal loss in the frontal and temporal cortices, hippocampal CA2/3 subregions, SNpc, and DMV, and widespread neuronal $\alpha \mathrm{S}$ immunoreactive inclusions, suggesting that $\alpha \mathrm{S}$ may contribute to cognitive decline [109]. In a comprehensive MDSGene review, cognitive decline was described in 70\% of SNCA mutation carriers [110]. A meta-analysis conducted by Marsili et al. evaluated the different timelines to postural instability and other milestones signaling advanced disease, including autonomic dysfunction and cognitive impairment, in monogenic PD. In PD patients with the SNCA mutation, the most prevalent milestones is autonomic dysfunction (29\%) [111]. Since autonomic dysfunction is a prevalent symptom in PDD [112], it is proposed that the connection between autonomic dysfunction and cognitive impairment is the extensive $\alpha \mathrm{S}$ pathology in both PNS and CNS. Apart from $S N C A$, other PD-related genes such as leucine-rich repeat kinase 2 (LRRK2), glucocerebrosidase $(G B A)$, and parkin also have been linked to alterations in $\alpha S$ levels.

\section{- $\quad$ LRRK2}

Although an appreciable subset of $L R R K 2$ PD cases display neuronal loss in the SNpc without LB pathology [113], there is emerging evidence for interplay between LRRK2 and $\alpha$ S. In a postmortem study in PD patients with the LRRK2 G2019S mutation, cognitive decline was correlated with the presence of LB pathology [114].

Aging affects fundamental cellular machinery by increased oxidative stress and impaired proteostasis $[115,116]$ and is considered a major risk factor for PD. LRRK2 mutations facilitate PD through several possible mechanisms. Among them, studies have pointed out the role of LRRK2 in autophagy. Tong et al. demonstrated renal atrophy and accumulation of phosphorylated $\alpha \mathrm{S}$ at $\mathrm{S} 129$ and ubiquitinated proteins in the kidneys in $L R R K 2^{-/-}$mice at 20 months of age [117]. Moreover, Tong and colleagues found an age-dependent biphasic alteration of the autophagic activity in LRRK2-/- kidneys, which would in turn result in protein accumulation and aggregation during aging [118]. Since $L R R K 2$ is a serine-threonine kinase, it has been suggested that G2019S mutant LRRK2 has increased kinase activity and can phosphorylate $\alpha S$, resulting in $\alpha$ S aggregation [119]. Recent studies suggest that LRRK2 is not the main kinase responsible for most $\alpha \mathrm{S}$ phosphorylation. Several kinases have been shown to be implicated in phosphorylating $\alpha S$, such as $G$ protein-coupled receptor kinases and polo-like kinases [120,121]. However, LRRK2 kinase still plays an important role in modulating $\alpha$ S aggregation in the CNS. Evidence suggests that Rab GTPases are cellular physiological substrates of $L R R K 2$ kinase. Steger and colleagues found that $L R R K 2$ phosphorylates endogenous Rab3A/B/C/D, Rab8A/B, Rab10, Rab12, Rab35, and Rab43 in cells through systemic assays using phosphoproteomics [122]. In primary cortical neurons, studies have shown that the phosphorylation of Rab35 mediates mutant LRRK2-induced toxicity [123]. In addition, $L R R K 2$-mediated Rab35 phosphorylation positively regulates $\alpha \mathrm{S}$ breeding, linking LRRK2 kinase activity to $\alpha \mathrm{S}$ aggregation [124]. Moreover, pathogenic $L R R K 2$ has been shown to alter vesicular trafficking events and endo-lysosomal functioning and to mediate $\alpha$ S propagation by phosphorylating Rab35 [124,125]. 


\section{- $G B A$}

One of the most common lysosomal storage disorders is Gaucher disease (GD), which is caused by a recessively inherited deficiency in $\beta$-glucocerebrosidase (Gcase) and subsequent accumulation of toxic lipid substrates. GBA mutations are the strongest genetic risk factor for PD and can also increase the risks of other $\alpha$-synucleinopathies [126-130]. Mutations and variations in the GBA gene are associated with more rapid disease progression and a three-fold increased risk for dementia compared with patients with PD [131]. In a pathological examination, widespread neocortical and limbic $\alpha$ S pathology tended to occur more frequently in the PD patients with GBA mutations compared with the patients with non-GBA mutations [132]. It has been shown that the major Gcase substrate, glucosylceramide, can directly influence the amyloid formation of $\alpha$ S by stabilizing soluble oligomeric intermediates. Functional loss of Gcase activity causes $\alpha \mathrm{S}$ accumulation and neurotoxicity through aggregation-dependent mechanisms in primary cultures and human iPS neurons [133]. It is thought that an escalating feedback loop might exist between Gcase and $\alpha S$ that can lead to the self-propagation of disease and eventually dementia. Accumulation of $\alpha \mathrm{S}$ can cause inhibition of Gcase by interfering with endoplasmic reticulum-to-Golgi trafficking, which in turn, leads to decreased Gcase activity and promotes the accumulation of $\alpha \mathrm{S}$ [133].

\section{- $\quad$ Parkin/PINK1}

These genes are discussed together as their protein products are linked to mitochondrial function, and their biallelic loss-of-function mutations all cause autosomal recessive young-onset PD [134-136]. Parkin is an E3 ubiquitin ligase that mediates numerous cellular processes connected to mitochondria. Parkin over-expressing animal models are protected against $\alpha \mathrm{S}$ toxicity $[137,138]$, suggesting a link between $\alpha \mathrm{S}$ and parkin. In a transgenic animal model, parkin co-expression with $\alpha \mathrm{S}$ reduced the levels of phosphorylated $\alpha \mathrm{S}$ and attenuated cell death and inflammation [139]. PINK1 is a serine/threonine kinase acting as a molecular sensor of mitochondrial quality that accumulates on the outer membrane surface of dysfunctional mitochondria where it simultaneously recruits and activates parkin's E3 ubiquitin ligase activity. This triggers multiple signaling events to degrade damaged mitochondria via the mitophagy pathway [120]. Parkin-associated PD has been considered a non-LB disorder, with a few reported exceptions in compound heterozygous mutation carriers [140-142]. Clinically, patients with a parkin or PINK1 mutation have slower motor and neurocognitive progression $[143,144]$.

\subsubsection{Non-PD Related Genes}

It has been proposed that other traditionally non-PD-related genetic variations are also accountable for developing PDD. Common genetic variation of the apolipoprotein $\mathrm{E}$ $(A P O E) \varepsilon 4$ allele and microtubule-associated protein tau (MAPT) H1-haplotype have been linked to earlier development of dementia in patients with PD [145].

- $\quad A P O E$

Apart from being the strongest genetic risk factor for late-onset $\mathrm{AD}$, the $A P O E \varepsilon 4$ allele has also been found to be a genetic risk factor for both LBD and PDD [146-149]. In a postmortem study, APOE $\varepsilon 4$ has been associated with the severity of LB pathology independently of AD pathology [150]. In a recent case-control GWAS in three large longitudinal PD cohorts, $A P O E \varepsilon 4 / \varepsilon 4$ individuals showed significant cognitive decline over time [151]. In a double transgenic mouse model on an APOE knockout (A53T/EKO) or human APOE knockin (A53T/E2, E3, or E4), A53T/E4 mice accumulated higher amounts of brainstem $\alpha \mathrm{S}$ compared with A53T/EKO and A53T/E3 mice [152]. In a human APOE-targeted replacement murine model expressing APOE2, APOE3, or APOE4, delivery of overexpressed human wild-type $\alpha \mathrm{S}$ using adeno-associated virus demonstrated that $A P O E 4$ exacerbated $\alpha S$ pathology in the absence of amyloids [153]. To sum up, APOE directly regulates $\alpha S$ pathology and hence disease progression towards PDD. 


\section{- $\quad$ MAPT}

Human tau is a microtubule-binding protein encoded by the MAPT gene. In different GWAS studies investigating the influence of common genetic variations in PD, MAPT is one of the significant associations that have been replicated. The genetic architecture of MAPT has been evaluated in a Caucasian European ancestry cohort of PD patients without dementia. There is a statistically significant association between the H1 haplotype and PD risk, especially in non-tremor dominant PD [154]. It is worth noting that co-aggregation of $\alpha \mathrm{S}$ and tau filamentous inclusions has been found in human and PD transgenic mice brains and oligodendrocytes. The co-incubation of tau and $\alpha \mathrm{S}$ synergistically promotes the fibrillization of both proteins [155]. This suggests that tau may have potential roles in contributing to the development of PDD. SNCA and MAPT genes interact in affecting risk for PD. Many other studies have discovered that $M A P T$ is an independent risk factor for the development of cognitive impairment or dementia in PD patients [156,157]. One study analyzing an SNCA risk allele combined with the MAPT H1-haplotype suggests they cause a synergistic increase in the susceptibility of developing dementia in patients with PD [158]. Conversely, some studies have reported no genetic interaction between SNCA and the MAPT polymorphism [159-162].

\subsubsection{Polygenic Risk Score (PRS) in PDD}

Polygenic risk score is a numerical indicator that summarizes the estimated risk based on multiple genetic markers associated with a disease or a trait [163]. Both the recent PD GWAS in European [146] and Asian [164] populations have been deployed as references used to build a PD-related PRS. A PD GWAS browser tool (https:/ / pdgenetics. shinyapps.io/GWASBrowser/, accessed on 12 October 2021) has also been created to assist $\mathrm{PD}$ research. Several genetic loci have been implicated in influencing cognitive function in PD. In a population-based study, a higher polygenic risk score was associated with faster cognitive decline [165]. This finding suggests that PDD may be induced by the cumulative dysfunction of multiple cellular pathways.

\subsection{Alpha-Synuclein Propagation}

A detailed neuropathological examination by Braak and colleagues demonstrated a sequential caudal-to-rostral progression of $\alpha \mathrm{S}$ pathology from the dorsal motor nucleus of the vagus (DMV) in the caudal medulla in the early stage of PD to limbic and neocortical areas in the later stage [166,167]. Emerging evidence also suggests that $\alpha \mathrm{S}$ pathology can begin in the enteric or peripheral autonomic nervous system and invade the CNS via retrograde vagal transport (the dual-hit hypothesis). Despite some exceptions, the spatiotemporal progression of $\alpha S$ pathology in the majority of PD patients suggests that $\alpha S$ undergoes prion-like, cell-to-cell transmission within individuals. These hypotheses suppose that both neuronal vulnerability and connectivity are necessary to facilitate the propagation of $\alpha \mathrm{S}$ pathology along susceptible neurons.

The olfactory bulb is affected by $\alpha \mathrm{S}$ pathology in almost all cases of LBD and is considered as an entry site for prion-like propagation [168]. Since olfactory limbic structures are key components of cognitive processing, $\alpha \mathrm{S}$ involvement of olfactory, limbic, and neocortical structures in PD and DLB plays a crucial role in the development of dementia. There is close anatomical proximity of the olfactory bulb with limbic regions and projections to the neocortex. There is a putative olfactory/limbic pathway suggesting that $\alpha \mathrm{S}$ can propagate along the neuronal connections and induce neurocognitive impairment as $\alpha S$ pathology reaches the neocortex [169].

In a new hypothesis, PD is divided into brain-first (top-down) and body-first (bottomup) subtypes [170]. In the brain-first subtype, an $\alpha \mathrm{S}$ seed first develops in the CNS and injures dopaminergic neurons of the SNpc, which are the most vulnerable to $\alpha S$ pathology $[171,172]$. In the body-first subtype, $\alpha S$ pathology is initially found in the enteric nervous system and ascends via both the left and right DMV, owing to the overlapping parasympathetic innervation of the gut [173]. Thus, the clinical symptoms of the body-first 
PD subtype are relatively symmetric and exhibit more autonomic prodromal symptoms before the onset of parkinsonism. A recently proposed PD etiopathogenesis model called the Synuclein Origin and Connectome model (SOC model) posits that $\alpha \mathrm{S}$ pathobiology is the core feature of PD pathogenesis [174]. Moreover, the anatomical origin of the initial synuclein inclusion and dominant ipsilateral connectivity of the human brain may explain motor asymmetry, the presence of non-motor symptoms (for example, constipation and REM stage behavior disorder), and the variable rates of cognitive decline seen in different subtypes of PD. The presence of $\alpha$ S-containing LBs in neocortical and paralimbic regions is one of the main pathological hallmarks correlating with PDD $[175,176]$. It has been hypothesized that in body-first PD, as the $\alpha \mathrm{S}$ pathology propagates symmetrically from the PNS to the CNS, the total burden of $\alpha \mathrm{S}$ is higher, so the patients are more likely to develop dementia.

\subsection{Protein-Protein Interaction}

During protein biogenesis, proteins form multiple interactions with other proteins. Dysregulation of biological protein-protein interactions may result in $\alpha \mathrm{S}$ aggregation and eventually disease progression. Aggregation could be initiated by the loss of assistance during $\alpha \mathrm{S}$ biogenesis induced by mutations in $\alpha \mathrm{S}$, or a loss of interacting proteins. In a study using Ingenuity Pathway Analysis (IPA, Qiagen), $\alpha$ S-interacting partners can be categorized into seven different functional clusters including transcription, translation, folding/trafficking, modification, secretion, mitochondrial-associated, and degradation [177]. For example, chaperones assist protein folding and inhibit fiber assembly. Direct expression of the chaperone Hsp70 protected against $\alpha \mathrm{S}$ toxicity by preventing dopaminergic neuronal loss in Drosophila [178]. Another experiment showed that the chaperonin containing TCP-1 (CCT) can inhibit aggregation by interacting with the NAC domain of $\alpha \mathrm{S}$ A53T oligomers [179]. Co-translational and post-translational modifications can affect protein conformation, localization, and degradation. Post-translational modifications of $\alpha \mathrm{S}$ include nitration on tyrosine residues [180], ubiquitination [181], phosphorylation [182], C-terminal truncation [183], and SUMO modification [184]. Among them, the most attention has been devoted to phosphorylation at S129. It is still unclear whether $\alpha \mathrm{S}$ phosphorylation is a cause or a consequence of aggregation, or whether phosphorylation is neurotoxic or neuroprotective. Whereas only a small fraction ( $4 \%$ ) of soluble $\alpha \mathrm{S}$ monomer is phosphorylated under physiological conditions in vivo, approximately $90 \%$ of deposited $\alpha \mathrm{S}$ is phosphorylated at S129 within LBs $[182,185,186]$, suggesting that phosphorylation plays a crucial role in the regulation of $\alpha \mathrm{S}$ aggregation, LB formation, and neuronal degeneration. A study using peptide pulldown assays and mass spectrometry revealed differences in the protein-protein interactions of phosphorylated versus non-phosphorylated $\alpha \mathrm{S}$ [187]. Phosphorylated peptide containing the pS129 of $\alpha \mathrm{S}$ had a higher binding affinity for cytoskeletal proteins, vesicular trafficking proteins involved in endocytosis, and enzymes involved in protein serine phosphorylation. This result suggests that phosphorylation could promote the binding of $\alpha \mathrm{S}$ to the synaptic cytoskeleton and regulate the synaptic vesicle cycle. This is compatible with the fact that cortical LBs contain cytoskeletal proteins, including tau [188]. The non-phosphorylated peptide interacted preferentially with mitochondrial complexes I, III, and IV. By replacing S129 with either an alanine (S129A) to block phosphorylation, or with an aspartate (S129D) to mimic phosphorylation, studies have shown that overexpression of S129D $\alpha \mathrm{S}$ results in less neuronal death than overexpression of S129A $\alpha \mathrm{S}[189,190]$. These findings suggest that when levels of non-phosphorylated $\alpha \mathrm{S}$ are high, the protein may enter mitochondria and induce mitochondrial dysfunction and subsequent cell death.

The clearance of $\alpha \mathrm{S}$ involves a variety of extracellular and intracellular degradation systems that require well-regulated enzymatic reactions. Both monomeric and aggregated forms of $\alpha \mathrm{S}$ in the extracellular space can be cleared by internalization by neighboring neuronal cells including neurons, astrocytes, and microglia, and be degraded within the lysosome [191,192]. Intracellular $\alpha \mathrm{S}$ species are degraded by the complementary works of 
the proteasomal and lysosomal pathways. In the ubiquitin-dependent proteasome pathway, the enzymes E1, E2, and E3 activate ubiquitin and conjugate a ubiquitin chain to $\alpha \mathrm{S}$. After ubiquitination, the $\alpha$ S-polyubiquitin complex can be recognized by the $26 \mathrm{~S}$ proteasome and undergo degradation [193]. Ubiquitin-independent proteolysis may also occur for natively unfolded proteins [194]. Using rat pheochromocytoma PC12 cell lines, cells transfected with A53T human protein showed significantly strong staining for ubiquitin in the cytoplasm instead of the low-level diffuse staining seen in the empty vector-transfected or wild-type $\alpha$ S-transfected cell lines. Moreover, the A53T human $\alpha$ S-transfected PC12 cell line showed statistically significant lower proteasomal chymotrypsin-like activity then a wild-type $\alpha$-transfected cell line, suggesting the critical role of ubiquitination in proteostasis. The lysosome degrades intracellular proteins through the endosomal and three autophagic pathways: chaperone-mediated autophagy (CMA), macroautophagy, and microautophagy. In CMA, cytosolic chaperone heat-shock cognate 70 (hsc70) selectively recognizes a pentapeptide motif on the target protein (in $\alpha \mathrm{S},{ }_{95} \mathrm{VKKDQ}_{99}$ ) and this complex translocates to the lysosomal membrane and binds to the lysosome-associated transmembrane protein LAMP2A for subsequent degradation within the lysosomal lumen. In PC12 cells expressing a mutant $\alpha \mathrm{S}$ that lacks the CMA recognition motif and in which Lamp2a was downregulated by use of a small interfering RNA, higher levels of the mutant wild type $\alpha$ S were observed by immunoblotting [195].

Neurodegenerative diseases can have coexistence of different proteinopathies and heterogeneous clinical symptoms. Despite the central role of $\alpha$ S pathology in PDD, coexistent amyloid- $\beta(A \beta)$ and tau pathologies are also commonly found in neurodegenerative disorders, suggesting possible crosstalk between them. It has been shown that $A \beta$, tau, and $\alpha S$ fibrils promote the fibrillation and accumulation of one another in vitro $[155,196,197]$. In a transgenic mouse model expressing human $\alpha S, A \beta$ peptides, or both, double transgenic mice had severe deficits in learning and exhibited motor deficits before $\alpha \mathrm{S}$ single-transgenic mice [198]. Another bigenic mouse model with combined pathologies of tau and $\alpha \mathrm{S}$ demonstrated exacerbated behavioral impairment associated with accelerated pathological $\alpha S$ and tau [199]. $A \beta$ and tau pathologies independently contribute to the development of cognitive decline in PD but may also act synergistically with $\alpha \mathrm{S}$ pathology to confer a worse prognosis $[200,201]$. Nuclear imaging evidence obtained by using $\left[{ }^{18} \mathrm{~F}\right] \mathrm{AV}-1451$ tau PET and $\left[{ }^{11} \mathrm{C}\right] \mathrm{PiB}$ amyloid PET demonstrated that cortical tau aggregation was greater in DLB or PDD patients in comparison with PD subjects without cognitive decline and normal controls [202]. To clarify how $\alpha \mathrm{S}$ modulates tau spreading in mouse brains, in a recent study on mouse preformed fibrils, $\alpha \mathrm{S}$, enriched $\mathrm{AD}$ brain-derived tau, or the two in combination were injected into wild-type mice. $\alpha S$ staining was primarily found in the hippocampus and entorhinal cortex and revealed no major differences in the burden and spreading of $\alpha S$ between groups. On the other hand, tau pathology burden and spreading were significantly accelerated in the presence of $\alpha \mathrm{S}$ compared with injected tau alone. These findings point to the important role of $\alpha \mathrm{S}$ as a modulator of tau pathology burden [203].

\section{Alpha-Synuclein as a Biomarker of PDD}

\section{1. $\alpha S$, Amyloid- $\beta(A \beta)$, and Tau Pathology in PDD}

Some key unmet medical needs in PD include the inability to make a definitive diagnosis at the early stages, the lack of clear disease progression patterns, and the lack of disease-modifying therapies, which are not yet in sight. The natural course of motor and cognitive decline in PD can vary considerably, likely depending on variation in the underlying pathological characteristics. Identifying reliable biomarkers of cognitive decline in PD provides clues to disease progression.

The association between $\alpha \mathrm{S}$ levels in various tissues in the body and PD is well established. Cerebrospinal fluid (CSF) is often used as a source of biomarkers in neurological disorders because it may directly reflect changes and disease pathologies in the CNS. Lower $\alpha S$ levels in the CSF have been observed in patients with PD and related synucleinopathies compared with controls in many studies [204-208]. In the DATATOP cohort, lower CSF 
levels of total $\alpha$ S predicted better preservation of cognitive function in PD patients [209]. Another longitudinal follow-up study observed that higher total $\alpha$ S in CSF was associated with the rapid progression of both motor symptoms and cognitive decline in PD over 2 years [210].

CSF biomarker tests are invasive, making them unsuitable for office-based practice and repeated collection during the course of disease. The diagnostic value of other accessible, non-invasive, and highly reliable biomarker sources requires further investigation. Many studies have shown that plasma or serum $\alpha \mathrm{S}$ level correlates with motor severity and cognitive decline in patients with PD [211-213]. Although the level of saliva and urine $\alpha S$ did not yield a clear differential value, tear fluid revealed small but significant differences in total $\alpha$ S levels between PD and control subjects [214]. In a study investigating skin biopsies, a significant increase in $\alpha S$ seeding activity was observed in individuals with PD and synucleinopathies compared with controls with tauopathies and non-neurodegenerative diseases [215]. An in vivo study using $3 \mathrm{~mm}$ punch biopsies taken from the cervical C7 paravertebral area, thigh, and distal leg showed different skin $\alpha \mathrm{S}$ deposition patterns between synucleinopathies. For example, there is higher positivity of phosphorylated $\alpha S$ at S129 in cervical skin samples in PD and DLB. The occurrence of phosphorylated $\alpha S$ staining along skin nerves per sample was higher in DLB than PD. MSA displayed a unique pattern of $\alpha S$ pathology limited in somatosensory skin fibers [216].

As briefly discussed in the previous section, despite the central role of $\alpha \mathrm{S}$ pathology in PDD, coexistent amyloid- $\beta$ (A $\beta)$ and tau pathologies are also commonly found in neurodegenerative disorders. In fact, up to $50 \%$ of patients with PDD may exhibit comorbid $A D$ in postmortem studies [217-219]. Numerous studies have found that the levels of $A \beta$ plaques and tau tangles are also correlated with cognitive performance in patients with PDD [31,201,220,221]. Yu et al. used ELISA to show that an elevated level of CSF tau is significantly correlated with cognitive impairment in PD patients [222]. Liu et al. followed up the cognitive decline of PD patients for 4.3 years after the initiation of levodopa and found that CSF phosphorylated tau ( $\mathrm{p}$-tau) and the $\mathrm{p}$-tau:A $\beta 42$ ratio predict subsequent decline on cognitive tasks involving both memory and executive functions [223]. These results suggest that $\alpha \mathrm{S}$, tau, and $\mathrm{A} \beta$ could be used as potential biomarkers for PD patients with cognitive impairment.

\subsection{MicroRNAs as Biomarkers for PD/PDD}

Recently, microRNAs (miRNAs), small non-coding RNAs approximately 21-25 nucleotides in length, have been widely studied for their roles in silencing gene expression and as potential biomarkers for various diseases. Few miRNAs are currently used as biomarkers for PDD. Han et al. recruited 39 PD patients with normal cognition, 37 PD patients with mild cognitive impairment, and 22 PD patients with dementia (PDD), and used RT-qPCR to show that the levels of three miR-29s (miR-29a, miR-29b, and miR-29c) in the PDD group were significantly lower than those in the PD with normal cognition group. A significant association was found between miR-29s and PDD [224]. Yang et al. recruited 30 PD patients with dementia and 208 healthy controls and found a significant difference in miR-135a expression levels between the PDD group and healthy controls [225].

Because the number of PDD biomarker miRNAs is currently small, more research is required to discover new ones. Here we will first list miRNAs that have been reported to be associated with PD and then predict candidate miRNAs for PDD. Recent studies have identified several miRNAs that can directly or indirectly regulate the expression of $\alpha$ S. In PD patients, miR-7, miR-153, miR-34b/miR-34c, and miR214 have been reported to directly bind to $S N C A$ transcripts and regulate their modification [226]. Other miRNAs that indirectly impact $\alpha S$ without binding to $\alpha S$ include miR-21, miR-224, miR-373, miR-379, miR-128, let-7, miR-133b, miR-26b, miR-106a, miR-301b, miR-443, miR-15b-5p [226]; miR124 [227-229], miR-let-7d, miR-22, miR-23a, miR-24, miR-142-3p, miR-222 [230]; miR-27a3p, miR-125a-5p, miR-151a-3p, miR-423-5p, let-7f-5p [231]; miR-1, miR-19b-3p, miR-153, 
miR-409-3p, miR-10a-5p [232]; and miR-16-1, miR-138-2-3p, miR-205, miR-224, miR-320a, miR-373, miR-379, miR-494, miR-4639-5p [233].

As previously discussed, $\mathrm{AD}$ neuropathology (especially tau and $\mathrm{A} \beta$ aggregates) appears to play an important role in the pathogenesis of PDD in a significant proportion of patients. The pathomorphologic characteristics of PDD/DLB seem to cover the neuropathological features of both PD and AD [220]. In order to identify more potential biomarkers for PDD, three miRNAs, miR124, miR-7f-5p, and miR153, that are reported to be correlated with both PD and AD, will be briefly introduced. miRNA-124 is downregulated in AD, PD, and HD [227]. A recent study pointed out the potential importance of miR-124-dependent gene networks in PD, as nearly $25 \%$ of validated miR- 124 targets are deregulated in this disease [234]. miR-124 and miR-7f-5p are also deregulated in the hippocampus of patients with late-onset Alzheimer's disease [235]. miRNA-153 can directly target SNCA transcripts and downregulate $\alpha \mathrm{S}$ expression [236]. On the other hand, Liang et al. used a miR-153 transgenic mouse model and showed that miR-153 downregulated the expression of amyloid precursor protein (APP) and amyloid precursor-like protein 2 (APLP2) proteins in vivo [237]. Because of their dual functional roles in both PD and AD, these miRNAs are predicted to be more likely to contribute to PDD pathology.

\subsection{EV Proteins as Biomarkers for PD/PDD}

The $\alpha \mathrm{S}$ in the plasma, CSF, and tissue can be derived from extracellular vesicles (EVs) or released from cells via an unconventional protein secretion mechanism [96,238]. However, $\alpha S$ derived from the blood, CSF, or tissues may suffer from external contamination and thus its levels cannot accurately reflect the internal status of the neurons. Lin et al. showed that the levels of circulating free-form $\alpha \mathrm{S}$ and tau do not correlate well with cognitive score based on the minimal mental status exam (MMSE) in PD [212]. A novel platform for biomarker identification is EVs. EVs are lipid bilayer-encapsulated particles secreted by cells. They carry many molecules, including proteins, metabolites, and nucleic acids [239]. CNS-derived EVs can cross the blood-brain barrier and remain stable in the periphery, preventing the CNS biomarkers from being degraded and allowing them to reflect the intraneuronal condition. There are more and more studies on the relationship between EVs and other neurodegenerative dementias. In $\mathrm{AD}$, plasma neural-derived exosomes show significantly higher levels of $A \beta 1-42$ and total tau than controls [240]. A study using neuralderived small EVs showed a specific miRNA signature in AD [241]. In DLB, exosomal $\alpha \mathrm{S}$ levels correlate with the severity of cognitive impairment [242]. Exosomal $\alpha S$ levels can distinguish PD from other atypical parkinsonism [243]. The EV-derived neurofilament light chain [244] and phosphorylated insulin receptor 1 [245] are also associated with the severity of rigidity and tremor in $\mathrm{PD}$, respectively. In a recent study, plasma EV $\alpha \mathrm{S}$ levels were significantly lower in patients with PD compared with controls, and inversely associated with akinetic-rigidity severity [246]. In another study, the plasma EV $\alpha S$ level was higher in PD patients [247]. The distinction between the two studies may arise from the methods used to purify the heterogeneous population of EVs and the analytical procedures used to detect $\alpha \mathrm{S}$. Other studies suggest that exosomal $\alpha \mathrm{S}$ can contribute to interneuronal disease transmission [248,249]. Emerging evidence supports the potential application of EVs as indicators of cognitive impairment; however, the research on the correlation between EVs and PDD is still limited. More studies are required to study the potential diagnostic or prognostic value of EV proteins in PD and PDD.

\section{Conclusions}

Genetic mutations, protein-protein interactions, protein propagation, and an imbalance between synthesis and degradation influence the aggregation propensity of $\alpha \mathrm{S}$. Further clinicopathological correlation and biomarker studies will help to further elucidate the interrelationships of $\alpha S$ pathology in PD and the development of dementia in patients with $\mathrm{PD}$. Moreover, visualizing $\alpha \mathrm{S}$ pathology propagation in vivo to assess its temporal 
relationship to cognitive decline is warranted. These discoveries will be crucial in the development of meaningful disease-modifying or neuroprotective therapies for PDD.

Author Contributions: T.-S.F., S.C.-H.L. and R.-M.W. wrote the manuscript; Conceptualization, supervision, review and finalized the manuscript: R.-M.W.; Original draft preparation, review and editing the introduction, dementia, genetics, and protein-protein interaction sections: T.-S.F.; Review and editing the alpha-synuclein toxicity, PD/PDD biomarkers microRNAs and EV proteins sections; All authors have read and agreed to the published version of the manuscript.

Funding: This work was supported by the Ministry of Science and Technology Taiwan (R.O.C.) under grant numbers: MOST 109-2314-B-002-120-MY3.

Institutional Review Board Statement: Not applicable.

Informed Consent Statement: Not applicable.

Acknowledgments: We thank Teh-Cheng Wang and the staff of the Second Core Lab, Department of Medical Research, National Taiwan University Hospital for technical support and advice during the study.

Conflicts of Interest: The authors declare no conflict of interest.

\section{References}

1. Postuma, R.B.; Berg, D.; Stern, M.; Poewe, W.; Olanow, C.W.; Oertel, W.; Obeso, J.; Marek, K.; Litvan, I.; Lang, A.E.; et al. MDS clinical diagnostic criteria for Parkinson's disease. Mov. Disord. Off. J. Mov. Disord. Soc. 2015, 30, 1591-1601. [CrossRef] [PubMed]

2. Chaudhuri, K.R.; Healy, D.G.; Schapira, A.H.V. Non-motor symptoms of Parkinson's disease: Diagnosis and management. Lancet Neurol. 2006, 5, 235-245. [CrossRef]

3. Sauerbier, A.; Jenner, P.; Todorova, A.; Chaudhuri, K.R. Non motor subtypes and Parkinson's disease. Parkinsonism Relat. Disord. 2016, 22 (Suppl. 1), S41-S46. [CrossRef]

4. Muslimovic, D.; Post, B.; Speelman, J.D.; Schmand, B. Cognitive profile of patients with newly diagnosed Parkinson disease. Neurology 2005, 65, 1239-1245. [CrossRef]

5. Szeto, J.Y.Y.; Walton, C.C.; Rizos, A.; Martinez-Martin, P.; Halliday, G.M.; Naismith, S.L.; Chaudhuri, K.R.; Lewis, S.J.G. Dementia in long-term Parkinson's disease patients: A multicentre retrospective study. NPJ Parkinsons Dis. 2020, 6, 2. [CrossRef]

6. Foltynie, T.; Brayne, C.E.; Robbins, T.W.; Barker, R.A. The cognitive ability of an incident cohort of Parkinson's patients in the UK. The CamPaIGN study. Brain 2004, 127, 550-560. [CrossRef]

7. Wojtala, J.; Heber, I.A.; Neuser, P.; Heller, J.; Kalbe, E.; Rehberg, S.P.; Storch, A.; Linse, K.; Schneider, C.; Gräber, S.; et al. Cognitive decline in Parkinson's disease: The impact of the motor phenotype on cognition. J. Neurol. Neurosurg. Psychiatry 2019, 90, 171-179. [CrossRef]

8. Goldman, J.G.; Litvan, I. Mild cognitive impairment in Parkinson's disease. Minerva Med. 2011, 102, 441-459. [PubMed]

9. Aarsland, D.; Andersen, K.; Larsen, J.P.; Lolk, A.; Nielsen, H.; Kragh-Sorensen, P. Risk of dementia in Parkinson's disease: A community-based, prospective study. Neurology 2001, 56, 730-736. [CrossRef] [PubMed]

10. Padovani, A.; Costanzi, C.; Gilberti, N.; Borroni, B. Parkinson's disease and dementia. Neurol. Sci. 2006, 27 (Suppl. 1), S40-S43. [CrossRef]

11. Hely, M.A.; Reid, W.G.; Adena, M.A.; Halliday, G.M.; Morris, J.G. The Sydney multicenter study of Parkinson's disease: The inevitability of dementia at 20 years. Mov. Disord. Off. J. Mov. Disord. Soc. 2008, 23, 837-844. [CrossRef] [PubMed]

12. Aarsland, D.; Kurz, M.W. The epidemiology of dementia associated with Parkinson disease. J. Neurol. Sci. 2010, 289, 18-22. [CrossRef]

13. Churchyard, A.; Lees, A.J. The relationship between dementia and direct involvement of the hippocampus and amygdala in Parkinson's disease. Neurology 1997, 49, 1570-1576. [CrossRef] [PubMed]

14. Hurtig, H.I.; Trojanowski, J.Q.; Galvin, J.; Ewbank, D.; Schmidt, M.L.; Lee, V.M.; Clark, C.M.; Glosser, G.; Stern, M.B.; Gollomp, S.M.; et al. Alpha-synuclein cortical Lewy bodies correlate with dementia in Parkinson's disease. Neurology 2000, 54, 1916-1921. [CrossRef]

15. Bertrand, E.; Lechowicz, W.; Szpak, G.M.; Lewandowska, E.; Dymecki, J.; Wierzba-Bobrowicz, T. Limbic neuropathology in idiopathic Parkinson's disease with concomitant dementia. Folia Neuropathol. 2004, 42, 141-150. [PubMed]

16. Mattila, P.M.; Rinne, J.O.; Helenius, H.; Dickson, D.W.; Röyttä, M. Alpha-synuclein-immunoreactive cortical Lewy bodies are associated with cognitive impairment in Parkinson's disease. Acta Neuropathol. 2000, 100, 285-290. [CrossRef] [PubMed]

17. Kövari, E.; Gold, G.; Herrmann, F.R.; Canuto, A.; Hof, P.R.; Bouras, C.; Giannakopoulos, P. Lewy body densities in the entorhinal and anterior cingulate cortex predict cognitive deficits in Parkinson's disease. Acta Neuropathol. 2003, 106, 83-88. [CrossRef]

18. Lo, R.Y.; Tanner, C.M.; Albers, K.B.; Leimpeter, A.D.; Fross, R.D.; Bernstein, A.L.; McGuire, V.; Quesenberry, C.P.; Nelson, L.M.; Van Den Eeden, S.K. Clinical features in early Parkinson disease and survival. Arch. Neurol. 2009, 66, 1353-1358. [CrossRef] 
19. Rosenthal, E.; Brennan, L.; Xie, S.; Hurtig, H.; Milber, J.; Weintraub, D.; Karlawish, J.; Siderowf, A. Association between cognition and function in patients with Parkinson disease with and without dementia. Mov. Disord. Off. J. Mov. Disord. Soc. 2010, 25, 1170-1176. [CrossRef] [PubMed]

20. Jenner, P.; Morris, H.R.; Robbins, T.W.; Goedert, M.; Hardy, J.; Ben-Shlomo, Y.; Bolam, P.; Burn, D.; Hindle, J.V.; Brooks, D. Parkinson's disease-the debate on the clinical phenomenology, aetiology, pathology and pathogenesis. J. Parkinsons Dis. 2013, 3, 1-11. [CrossRef]

21. Coon, E.A.; Mandrekar, J.N.; Berini, S.E.; Benarroch, E.E.; Sandroni, P.; Low, P.A.; Singer, W. Predicting phenoconversion in pure autonomic failure. Neurology 2020, 95, e889-e897. [CrossRef] [PubMed]

22. Boeve, B.F.; Silber, M.H.; Ferman, T.J.; Lucas, J.A.; Parisi, J.E. Association of REM sleep behavior disorder and neurodegenerative disease may reflect an underlying synucleinopathy. Mov. Disord. Off. J. Mov. Disord. Soc. 2001, 16, 622-630. [CrossRef] [PubMed]

23. Postuma, R.B.; Iranzo, A.; Hu, M.; Högl, B.; Boeve, B.F.; Manni, R.; Oertel, W.H.; Arnulf, I.; Ferini-Strambi, L.; Puligheddu, M.; et al. Risk and predictors of dementia and parkinsonism in idiopathic REM sleep behaviour disorder: A multicentre study. Brain 2019, 142, 744-759. [CrossRef]

24. Galvin, J.E.; Uryu, K.; Lee, V.M.-Y.; Trojanowski, J.Q. Axon pathology in Parkinson's disease and Lewy body dementia hippocampus contains $\alpha-, \beta-$, and $\gamma$-synuclein. Proc. Natl. Acad. Sci. USA 1999, 96, 13450-13455. [CrossRef] [PubMed]

25. Spillantini, M.G.; Schmidt, M.L.; Lee, V.M.-Y.; Trojanowski, J.Q.; Jakes, R.; Goedert, M. $\alpha$-Synuclein in Lewy bodies. Nature 1997, 388, 839-840. [CrossRef]

26. Spillantini, M.G.; Crowther, R.A.; Jakes, R.; Cairns, N.J.; Lantos, P.L.; Goedert, M. Filamentous $\alpha$-synuclein inclusions link multiple system atrophy with Parkinson's disease and dementia with Lewy bodies. Neurosci. Lett. 1998, 251, 205-208. [CrossRef]

27. Beyer, K.; Domingo-Sàbat, M.; Ariza, A. Molecular pathology of Lewy body diseases. Int. J. Mol. Sci. 2009, 10, 724-745. [CrossRef] [PubMed]

28. Kosaka, K. Latest concept of Lewy body disease. Psychiatry Clin. Neurosci. 2014, 68, 391-394. [CrossRef]

29. Emre, M.; Aarsland, D.; Brown, R.; Burn, D.J.; Duyckaerts, C.; Mizuno, Y.; Broe, G.A.; Cummings, J.; Dickson, D.W.; Gauthier, S.; et al. Clinical diagnostic criteria for dementia associated with Parkinson's disease. Mov. Disord. Off. J. Mov. Disord. Soc. 2007, 22, 1689-1707. [CrossRef]

30. McKeith, I.G.; Boeve, B.F.; Dickson, D.W.; Halliday, G.; Taylor, J.-P.; Weintraub, D.; Aarsland, D.; Galvin, J.; Attems, J.; Ballard, C.G.; et al. Diagnosis and management of dementia with Lewy bodies: Fourth consensus report of the DLB Consortium. Neurology 2017, 89, 88-100. [CrossRef]

31. Compta, Y.; Parkkinen, L.; O’Sullivan, S.S.; Vandrovcova, J.; Holton, J.L.; Collins, C.; Lashley, T.; Kallis, C.; Williams, D.R.; de Silva, R.; et al. Lewy- and Alzheimer-type pathologies in Parkinson's disease dementia: Which is more important? Brain 2011, 134, 1493-1505. [CrossRef]

32. Bohnen, N.I.; Kaufer, D.I.; Ivanco, L.S.; Lopresti, B.; Koeppe, R.A.; Davis, J.G.; Mathis, C.A.; Moore, R.Y.; DeKosky, S.T. Cortical cholinergic function is more severely affected in parkinsonian dementia than in Alzheimer disease: An in vivo positron emission tomographic study. Arch. Neurol. 2003, 60, 1745-1748. [CrossRef]

33. Cersosimo, M.G. Propagation of alpha-synuclein pathology from the olfactory bulb: Possible role in the pathogenesis of dementia with Lewy bodies. Cell Tissue Res. 2018, 373, 233-243. [CrossRef]

34. Smirnov, D.S.; Galasko, D.; Edland, S.D.; Filoteo, J.V.; Hansen, L.A.; Salmon, D.P. Cognitive decline profiles differ in Parkinson disease dementia and dementia with Lewy bodies. Neurology 2020, 94, e2076-e2087. [CrossRef] [PubMed]

35. Schirinzi, T.; Canevelli, M.; Suppa, A.; Bologna, M.; Marsili, L. The continuum between neurodegeneration, brain plasticity, and movement: A critical appraisal. Rev. Neurosci. 2020, 31, 723-742. [CrossRef]

36. Chan, F.; Lax, N.Z.; Davies, C.H.; Turnbull, D.M.; Cunningham, M.O. Neuronal oscillations: A physiological correlate for targeting mitochondrial dysfunction in neurodegenerative diseases? Neuropharmacology 2016, 102, 48-58. [CrossRef]

37. Maroteaux, L.; Campanelli, J.T.; Scheller, R.H. Synuclein: A neuron-specific protein localized to the nucleus and presynaptic nerve terminal. J. Neurosci. 1988, 8, 2804-2815. [CrossRef]

38. Bartels, T.; Ahlstrom, L.S.; Leftin, A.; Kamp, F.; Haass, C.; Brown, M.F.; Beyer, K. The N-terminus of the intrinsically disordered protein $\alpha$-synuclein triggers membrane binding and helix folding. Biophys. J. 2010, 99, 2116-2124. [CrossRef]

39. Rodriguez, J.A.; Ivanova, M.I.; Sawaya, M.R.; Cascio, D.; Reyes, F.E.; Shi, D.; Sangwan, S.; Guenther, E.L.; Johnson, L.M.; Zhang, M.; et al. Structure of the toxic core of $\alpha$-synuclein from invisible crystals. Nature 2015, 525, 486-490. [CrossRef]

40. Souza, J.M.; Giasson, B.I.; Lee, V.M.; Ischiropoulos, H. Chaperone-like activity of synucleins. FEBS Lett. 2000, 474, 116-119. [CrossRef]

41. Sorrentino, Z.A.; Giasson, B.I. The emerging role of $\alpha$-synuclein truncation in aggregation and disease. J. Biol. Chem. 2020, 295, 10224-10244. [CrossRef]

42. Burré, J.; Sharma, M.; Südhof, T.C. Definition of a molecular pathway mediating $\alpha$-synuclein neurotoxicity. J. Neurosci. Off. J. Soc. Neurosci. 2015, 35, 5221-5232. [CrossRef]

43. Nakamura, K.; Nemani, V.M.; Azarbal, F.; Skibinski, G.; Levy, J.M.; Egami, K.; Munishkina, L.; Zhang, J.; Gardner, B.; Wakabayashi, J.; et al. Direct membrane association drives mitochondrial fission by the Parkinson disease-associated protein alpha-synuclein. $J$. Biol. Chem. 2011, 286, 20710-20726. [CrossRef] [PubMed]

44. Bridi, J.C.; Hirth, F. Mechanisms of $\alpha$-Synuclein Induced Synaptopathy in Parkinson's Disease. Front. Neurosci. 2018, 12, 80. [CrossRef] 
45. Burré, J. The Synaptic Function of $\alpha$-Synuclein. J. Parkinsons Dis. 2015, 5, 699-713. [CrossRef] [PubMed]

46. Wakabayashi, K.; Tanji, K.; Mori, F.; Takahashi, H. The Lewy body in Parkinson's disease: Molecules implicated in the formation and degradation of alpha-synuclein aggregates. Neuropathology 2007, 27, 494-506. [CrossRef]

47. Shahmoradian, S.H.; Lewis, A.J.; Genoud, C.; Hench, J.; Moors, T.E.; Navarro, P.P.; Castaño-Díez, D.; Schweighauser, G.; GraffMeyer, A.; Goldie, K.N.; et al. Lewy pathology in Parkinson's disease consists of crowded organelles and lipid membranes. Nat. Neurosci. 2019, 22, 1099-1109. [CrossRef]

48. Dettmer, U.; Newman, A.J.; Soldner, F.; Luth, E.S.; Kim, N.C.; Von Saucken, V.E.; Sanderson, J.B.; Jaenisch, R.; Bartels, T.; Selkoe, D. Parkinson-causing $\alpha$-synuclein missense mutations shift native tetramers to monomers as a mechanism for disease initiation. Nat. Commun. 2015, 6, 1-16. [CrossRef]

49. Ferreon, A.C.M.; Gambin, Y.; Lemke, E.A.; Deniz, A.A. Interplay of $\alpha$-synuclein binding and conformational switching probed by single-molecule fluorescence. Proc. Natl. Acad. Sci. USA 2009, 106, 5645-5650. [CrossRef] [PubMed]

50. Frimpong, A.K.; Abzalimov, R.R.; Uversky, V.N.; Kaltashov, I.A. Characterization of intrinsically disordered proteins with electrospray ionization mass spectrometry: Conformational heterogeneity of $\alpha$-synuclein. Proteins Struct. Funct. Bioinform. 2010, 78, 714-722. [CrossRef]

51. Rokad, D.; Ghaisas, S.; Harischandra, D.S.; Jin, H.; Anantharam, V.; Kanthasamy, A.; Kanthasamy, A.G. Role of neurotoxicants and traumatic brain injury in $\alpha$-synuclein protein misfolding and aggregation. Brain Res. Bull. 2017, 133, 60-70. [CrossRef]

52. Guhathakurta, S.; Bok, E.; Evangelista, B.A.; Kim, Y.-S. Deregulation of $\alpha$-synuclein in Parkinson's disease: Insight from epigenetic structure and transcriptional regulation of SNCA. Prog. Neurobiol. 2017, 154, 21-36. [CrossRef] [PubMed]

53. Alam, P.; Bousset, L.; Melki, R.; Otzen, D.E. $\alpha$-synuclein oligomers and fibrils: A spectrum of species, a spectrum of toxicities. J. Neurochem. 2019, 150, 522-534. [CrossRef] [PubMed]

54. Cremades, N.; Chen, S.; Dobson, C. Structural characteristics of $\alpha$-synuclein oligomers. Int. Rev. Cell Mol. Biol. 2017, 329, 79-143. [PubMed]

55. Peelaerts, W.; Bousset, L.; Van der Perren, A.; Moskalyuk, A.; Pulizzi, R.; Giugliano, M.; Van den Haute, C.; Melki, R.; Baekelandt, V. $\alpha$-Synuclein strains cause distinct synucleinopathies after local and systemic administration. Nature 2015, 522, 340-344. [CrossRef]

56. Chen, S.W.; Drakulic, S.; Deas, E.; Ouberai, M.; Aprile, F.A.; Arranz, R.; Ness, S.; Roodveldt, C.; Guilliams, T.; De-Genst, E.J. Structural characterization of toxic oligomers that are kinetically trapped during $\alpha$-synuclein fibril formation. Proc. Natl. Acad. Sci. USA 2015, 112, E1994-E2003. [CrossRef]

57. Cremades, N.; Cohen, S.I.; Deas, E.; Abramov, A.Y.; Chen, A.Y.; Orte, A.; Sandal, M.; Clarke, R.W.; Dunne, P.; Aprile, F.A. Direct observation of the interconversion of normal and toxic forms of $\alpha$-synuclein. Cell 2012, 149, 1048-1059. [CrossRef]

58. Fusco, G.; Chen, S.W.; Williamson, P.T.; Cascella, R.; Perni, M.; Jarvis, J.A.; Cecchi, C.; Vendruscolo, M.; Chiti, F.; Cremades, N. Structural basis of membrane disruption and cellular toxicity by $\alpha$-synuclein oligomers. Science 2017, 358, 1440-1443. [CrossRef]

59. Gath, J.; Bousset, L.; Habenstein, B.; Melki, R.; Böckmann, A.; Meier, B.H. Unlike twins: An NMR comparison of two $\alpha$-synuclein polymorphs featuring different toxicity. PLoS ONE 2014, 9, e90659. [CrossRef]

60. Monsellier, E.; Bousset, L.; Melki, R. $\alpha$-Synuclein and huntingtin exon 1 amyloid fibrils bind laterally to the cellular membrane. Sci. Rep. 2016, 6, 19180. [CrossRef]

61. Pieri, L.; Madiona, K.; Bousset, L.; Melki, R. Fibrillar $\alpha$-synuclein and huntingtin exon 1 assemblies are toxic to the cells. Biophys. J. 2012, 102, 2894-2905. [CrossRef]

62. Paslawski, W.; Andreasen, M.; Nielsen, S.B.; Lorenzen, N.; Thomsen, K.; Kaspersen, J.D.; Pedersen, J.S.; Otzen, D.E. High stability and cooperative unfolding of $\alpha$-synuclein oligomers. Biochemistry 2014, 53, 6252-6263. [CrossRef] [PubMed]

63. Mahul-Mellier, A.-L.; Burtscher, J.; Maharjan, N.; Weerens, L.; Croisier, M.; Kuttler, F.; Leleu, M.; Knott, G.W.; Lashuel, H.A. The process of Lewy body formation, rather than simply $\alpha$-synuclein fibrillization, is one of the major drivers of neurodegeneration. Proc. Natl. Acad. Sci. USA 2020, 117, 4971-4982. [CrossRef] [PubMed]

64. Boutros, S.W.; Raber, J.; Unni, V.K. Effects of Alpha-Synuclein Targeted Antisense Oligonucleotides on Lewy Body-Like Pathology and Behavioral Disturbances Induced by Injections of Pre-Formed Fibrils in the Mouse Motor Cortex. J. Parkinsons Dis. 2021, 11, 1091-1115. [CrossRef]

65. Bernal-Conde, L.D.; Ramos-Acevedo, R.; Reyes-Hernández, M.A.; Balbuena-Olvera, A.J.; Morales-Moreno, I.D.; Argüero-Sánchez, R.; Schüle, B.; Guerra-Crespo, M. Alpha-Synuclein Physiology and Pathology: A Perspective on Cellular Structures and Organelles. Front. Neurosci. 2020, 13, 1399. [CrossRef]

66. Payton, J.E.; Perrin, R.J.; Woods, W.S.; George, J.M. Structural determinants of PLD2 inhibition by $\alpha$-synuclein. J. Mol. Biol. 2004, 337, 1001-1009. [CrossRef] [PubMed]

67. Dalfó, E.; Ferrer, I. $\alpha$-Synuclein binding to rab3a in multiple system atrophy. Neurosci. Lett. 2005, 380, 170-175. [CrossRef]

68. Burré, J.; Sharma, M.; Tsetsenis, T.; Buchman, V.; Etherton, M.R.; Südhof, T.C. $\alpha$-Synuclein promotes SNARE-complex assembly in vivo and in vitro. Science 2010, 329, 1663-1667. [CrossRef]

69. Zhu, M.; Li, J.; Fink, A.L. The association of $\alpha$-synuclein with membranes affects bilayer structure, stability, and fibril formation. J. Biol. Chem. 2003, 278, 40186-40197. [CrossRef]

70. Volles, M.J.; Lansbury, P.T. Vesicle permeabilization by protofibrillar $\alpha$-synuclein is sensitive to Parkinson's disease-linked mutations and occurs by a pore-like mechanism. Biochemistry 2002, 41, 4595-4602. [CrossRef] 
71. Kayed, R.; Sokolov, Y.; Edmonds, B.; McIntire, T.M.; Milton, S.C.; Hall, J.E.; Glabe, C.G. Permeabilization of lipid bilayers is a common conformation-dependent activity of soluble amyloid oligomers in protein misfolding diseases. J. Biol. Chem. 2004, 279, 46363-46366. [CrossRef] [PubMed]

72. Cecchi, C.; Stefani, M. The amyloid-cell membrane system. The interplay between the biophysical features of oligomers/fibrils and cell membrane defines amyloid toxicity. Biophys. Chem. 2013, 182, 30-43. [CrossRef]

73. Iyer, A.; Schilderink, N.; Claessens, M.M.; Subramaniam, V. Membrane-bound alpha synuclein clusters induce impaired lipid diffusion and increased lipid packing. Biophys. J. 2016, 111, 2440-2449. [CrossRef]

74. Logan, T.; Bendor, J.; Toupin, C.; Thorn, K.; Edwards, R.H. $\alpha$-Synuclein promotes dilation of the exocytotic fusion pore. Nat. Neurosci. 2017, 20, 681-689. [CrossRef] [PubMed]

75. Smith, P.E.; Brender, J.R.; Ramamoorthy, A. Induction of negative curvature as a mechanism of cell toxicity by amyloidogenic peptides: The case of islet amyloid polypeptide. J. Am. Chem. Soc. 2009, 131, 4470-4478. [CrossRef] [PubMed]

76. Soll, L.G.; Eisen, J.N.; Vargas, K.J.; Medeiros, A.T.; Hammar, K.M.; Morgan, J.R. $\alpha$-Synuclein-112 impairs synaptic vesicle recycling consistent with its enhanced membrane binding properties. Front. Cell Dev. Biol. 2020, 8, 405. [CrossRef]

77. Cooper, A.A.; Gitler, A.D.; Cashikar, A.; Haynes, C.M.; Hill, K.J.; Bhullar, B.; Liu, K.; Xu, K.; Strathearn, K.E.; Liu, F. $\alpha$-Synuclein blocks ER-Golgi traffic and Rab1 rescues neuron loss in Parkinson's models. Science 2006, 313, 324-328. [CrossRef]

78. Gosavi, N.; Lee, H.-J.; Lee, J.S.; Patel, S.; Lee, S.-J. Golgi fragmentation occurs in the cells with prefibrillar $\alpha$-synuclein aggregates and precedes the formation of fibrillar inclusion. J. Biol. Chem. 2002, 277, 48984-48992. [CrossRef]

79. Devi, L.; Raghavendran, V.; Prabhu, B.M.; Avadhani, N.G.; Anandatheerthavarada, H.K. Mitochondrial import and accumulation of $\alpha$-synuclein impair complex I in human dopaminergic neuronal cultures and Parkinson disease brain. J. Biol. Chem. 2008, 283, 9089-9100. [CrossRef]

80. Nakamura, K. $\alpha$-Synuclein and mitochondria: Partners in crime? Neurotherapeutics 2013, 10, 391-399. [CrossRef]

81. Gao, G.; Wang, Z.; Lu, L.; Duan, C.; Wang, X.; Yang, H. Morphological analysis of mitochondria for evaluating the toxicity of $\alpha$-synuclein in transgenic mice and isolated preparations by atomic force microscopy. Biomed. Pharmacother. 2017, 96, 1380-1388. [CrossRef] [PubMed]

82. Stefanis, L.; Larsen, K.E.; Rideout, H.J.; Sulzer, D.; Greene, L.A. Expression of A53T mutant but not wild-type $\alpha$-synuclein in PC12 cells induces alterations of the ubiquitin-dependent degradation system, loss of dopamine release, and autophagic cell death. J. Neurosci. 2001, 21, 9549-9560. [CrossRef]

83. Cuervo, A.M.; Stefanis, L.; Fredenburg, R.; Lansbury, P.T.; Sulzer, D. Impaired degradation of mutant $\alpha$-synuclein by chaperonemediated autophagy. Science 2004, 305, 1292-1295. [CrossRef] [PubMed]

84. Xilouri, M.; Brekk, O.R.; Stefanis, L. Alpha-synuclein and protein degradation systems: A reciprocal relationship. Mol. Neurobiol. 2013, 47, 537-551. [CrossRef] [PubMed]

85. Cookson, M.R. Alpha-Synuclein and neuronal cell death. Mol. Neurodegener. 2009, 4, 9. [CrossRef]

86. Rocha, E.M.; De Miranda, B.; Sanders, L.H. Alpha-synuclein: Pathology, mitochondrial dysfunction and neuroinflammation in Parkinson's disease. Neurobiol. Dis. 2018, 109, 249-257. [CrossRef]

87. Mullin, S.; Schapira, A. Alpha-Synuclein and mitochondrial dysfunction in Parkinson's disease. Mol. Neurobiol. 2013, 47, 587-597. [CrossRef]

88. Osterberg, V.R.; Spinelli, K.J.; Weston, L.J.; Luk, K.C.; Woltjer, R.L.; Unni, V.K. Progressive aggregation of alpha-synuclein and selective degeneration of lewy inclusion-bearing neurons in a mouse model of parkinsonism. Cell Rep. 2015, 10, 1252-1260. [CrossRef]

89. Volpicelli-Daley, L.A.; Luk, K.C.; Patel, T.P.; Tanik, S.A.; Riddle, D.M.; Stieber, A.; Meaney, D.F.; Trojanowski, J.Q.; Lee, V.M.-Y. Exogenous $\alpha$-synuclein fibrils induce Lewy body pathology leading to synaptic dysfunction and neuron death. Neuron 2011, 72, 57-71. [CrossRef]

90. Cavaliere, F.; Cerf, L.; Dehay, B.; Ramos-Gonzalez, P.; De Giorgi, F.; Bourdenx, M.; Bessede, A.; Obeso, J.A.; Matute, C.; Ichas, F. In vitro $\alpha$-synuclein neurotoxicity and spreading among neurons and astrocytes using Lewy body extracts from Parkinson disease brains. Neurobiol. Dis. 2017, 103, 101-112. [CrossRef]

91. Mezias, C.; Rey, N.; Brundin, P.; Raj, A. Neural connectivity predicts spreading of alpha-synuclein pathology in fibril-injected mouse models: Involvement of retrograde and anterograde axonal propagation. Neurobiol. Dis. 2020, 134, 104623. [CrossRef]

92. Hijaz, B.A.; Volpicelli-Daley, L.A. Initiation and propagation of alpha-synuclein aggregation in the nervous system. Mol. Neurodegener. 2020, 15, 19. [CrossRef] [PubMed]

93. Recasens, A.; Dehay, B.; Bové, J.; Carballo-Carbajal, I.; Dovero, S.; Pérez-Villalba, A.; Fernagut, P.O.; Blesa, J.; Parent, A.; Perier, C.; et al. Lewy body extracts from Parkinson disease brains trigger $\alpha$-synuclein pathology and neurodegeneration in mice and monkeys. Ann. Neurol. 2014, 75, 351-362. [CrossRef] [PubMed]

94. Howitt, J.; Hill, A.F. Exosomes in the Pathology of Neurodegenerative Diseases. J. Biol. Chem. 2016, 291, 26589-26597. [CrossRef]

95. Gousset, K.; Schiff, E.; Langevin, C.; Marijanovic, Z.; Caputo, A.; Browman, D.T.; Chenouard, N.; de Chaumont, F.; Martino, A.; Enninga, J.; et al. Prions hijack tunnelling nanotubes for intercellular spread. Nat. Cell Biol. 2009, 11, 328-336. [CrossRef]

96. Lee, H.J.; Patel, S.; Lee, S.J. Intravesicular localization and exocytosis of alpha-synuclein and its aggregates. J. Neurosci. 2005, 25, 6016-6024. [CrossRef]

97. Ghiglieri, V.; Calabrese, V.; Calabresi, P. Alpha-Synuclein: From Early Synaptic Dysfunction to Neurodegeneration. Front. Neurol. 2018, 9, 295. [CrossRef] 
98. Lashuel, H.A.; Overk, C.R.; Oueslati, A.; Masliah, E. The many faces of $\alpha$-synuclein: From structure and toxicity to therapeutic target. Nat. Rev. Neurosci. 2013, 14, 38-48. [CrossRef] [PubMed]

99. Roman-Vendrell, C.; Medeiros, A.T.; Sanderson, J.B.; Jiang, H.; Bartels, T.; Morgan, J.R. Effects of Excess Brain-Derived Human alpha-Synuclein on Synaptic Vesicle Trafficking. Front. Neurosci. 2021, 15, 639414. [CrossRef]

100. Wu, Q.; Takano, H.; Riddle, D.M.; Trojanowski, J.Q.; Coulter, D.A.; Lee, V.M. Alpha-Synuclein (alphaSyn) Preformed Fibrils Induce Endogenous alphaSyn Aggregation, Compromise Synaptic Activity and Enhance Synapse Loss in Cultured Excitatory Hippocampal Neurons. J. Neurosci. 2019, 39, 5080-5094. [CrossRef]

101. Cascella, R.; Chen, S.W.; Bigi, A.; Camino, J.D.; Xu, C.K.; Dobson, C.M.; Chiti, F.; Cremades, N.; Cecchi, C. The release of toxic oligomers from $\alpha$-synuclein fibrils induces dysfunction in neuronal cells. Nat. Commun. 2021, 12, 1814. [CrossRef] [PubMed]

102. Alza, N.P.; Iglesias Gonzalez, P.A.; Conde, M.A.; Uranga, R.M.; Salvador, G.A. Lipids at the Crossroad of alpha-Synuclein Function and Dysfunction: Biological and Pathological Implications. Front. Cell Neurosci. 2019, 13, 175. [CrossRef]

103. O'Leary, E.I.; Lee, J.C. Interplay between $\alpha$-synuclein amyloid formation and membrane structure. Biochim. Et Biophys. Acta (BBA)-Proteins Proteom. 2019, 1867, 483-491. [CrossRef] [PubMed]

104. Gelders, G.; Baekelandt, V.; Van der Perren, A. Linking Neuroinflammation and Neurodegeneration in Parkinson's Disease. J. Immunol. Res. 2018, 2018, 4784268. [CrossRef]

105. Rosborough, K.; Patel, N.; Kalia, L.V. $\alpha$-Synuclein and Parkinsonism: Updates and Future Perspectives. Curr. Neurol. Neurosci. Rep. 2017, 17, 31. [CrossRef]

106. Kasten, M.; Klein, C. The many faces of alpha-synuclein mutations. Mov. Disord. 2013, 28, 697-701. [CrossRef] [PubMed]

107. Zarranz, J.J.; Alegre, J.; Gomez-Esteban, J.C.; Lezcano, E.; Ros, R.; Ampuero, I.; Vidal, L.; Hoenicka, J.; Rodriguez, O.; Atares, B.; et al. The new mutation, E46K, of alpha-synuclein causes Parkinson and Lewy body dementia. Ann. Neurol. 2004, 55, 164-173. [CrossRef]

108. Carmona-Abellan, M.; Gabilondo, I.; Murueta-Goyena, A.; Khurana, V.; Tijero, B.; Luquin, M.R.; Acera, M.; Del Pino, R.; Gardeazabal, J.; Martínez-Valbuena, I.; et al. Small fiber neuropathy and phosphorylated alpha-synuclein in the skin of E46KSNCA mutation carriers. Parkinsonism Relat. Disord. 2019, 65, 139-145. [CrossRef]

109. Tokutake, T.; Ishikawa, A.; Yoshimura, N.; Miyashita, A.; Kuwano, R.; Nishizawa, M.; Ikeuchi, T. Clinical and neuroimaging features of patient with early-onset Parkinson's disease with dementia carrying SNCA p.G51D mutation. Parkinsonism Relat. Disord. 2014, 20, 262-264. [CrossRef] [PubMed]

110. Wittke, C.; Petkovic, S.; Dobricic, V.; Schaake, S.; Respondek, G.; Weissbach, A.; Madoev, H.; Trinh, J.; Vollstedt, E.J.; Kuhnke, N.; et al. Genotype-Phenotype Relations for the Atypical Parkinsonism Genes: MDSGene Systematic Review. Mov. Disord. Off. J. Mov. Disord. Soc. 2021, 36, 1499-1510. [CrossRef]

111. Marsili, L.; Vizcarra, J.A.; Sturchio, A.; Dwivedi, A.K.; Keeling, E.G.; Patel, D.; Mishra, M.; Farooqi, A.; Merola, A.; Fasano, A.; et al. When does postural instability appear in monogenic parkinsonisms? An individual-patient meta-analysis. J. Neurol. 2020, 268, 3203-3211. [CrossRef] [PubMed]

112. Allan, L.M.; Ballard, C.G.; Allen, J.; Murray, A.; Davidson, A.W.; McKeith, I.G.; Kenny, R.A. Autonomic dysfunction in dementia. J. Neurol. Neurosurg. Psychiatry 2007, 78, 671-677. [CrossRef]

113. Schneider, S.A.; Alcalay, R.N. Neuropathology of genetic synucleinopathies with parkinsonism: Review of the literature. Mov. Disord. Off. J. Mov. Disord. Soc. 2017, 32, 1504-1523. [CrossRef] [PubMed]

114. Kalia, L.V.; Lang, A.E.; Hazrati, L.N.; Fujioka, S.; Wszolek, Z.K.; Dickson, D.W.; Ross, O.A.; Van Deerlin, V.M.; Trojanowski, J.Q.; Hurtig, H.I.; et al. Clinical correlations with Lewy body pathology in LRRK2-related Parkinson disease. JAMA Neurol. 2015, 72, 100-105. [CrossRef]

115. Junqueira, V.B.; Barros, S.B.; Chan, S.S.; Rodrigues, L.; Giavarotti, L.; Abud, R.L.; Deucher, G.P. Aging and oxidative stress. Mol. Asp. Med. 2004, 25, 5-16. [CrossRef]

116. Lindner, A.B.; Demarez, A. Protein aggregation as a paradigm of aging. Biochim. Biophys. Acta 2009, 1790, 980-996. [CrossRef]

117. Tong, Y.; Yamaguchi, H.; Giaime, E.; Boyle, S.; Kopan, R.; Kelleher, R.J., 3rd; Shen, J. Loss of leucine-rich repeat kinase 2 causes impairment of protein degradation pathways, accumulation of alpha-synuclein, and apoptotic cell death in aged mice. Proc. Natl. Acad. Sci. USA 2010, 107, 9879-9884. [CrossRef] [PubMed]

118. Tong, Y.; Giaime, E.; Yamaguchi, H.; Ichimura, T.; Liu, Y.; Si, H.; Cai, H.; Bonventre, J.V.; Shen, J. Loss of leucine-rich repeat kinase 2 causes age-dependent bi-phasic alterations of the autophagy pathway. Mol. Neurodegener. 2012, 7, 2. [CrossRef]

119. Bieri, G.; Brahic, M.; Bousset, L.; Couthouis, J.; Kramer, N.J.; Ma, R.; Nakayama, L.; Monbureau, M.; Defensor, E.; Schüle, B.; et al. LRRK2 modifies $\alpha$-syn pathology and spread in mouse models and human neurons. Acta Neuropathol. 2019, 137, 961-980. [CrossRef]

120. Weston, L.J.; Stackhouse, T.L.; Spinelli, K.J.; Boutros, S.W.; Rose, E.P.; Osterberg, V.R.; Luk, K.C.; Raber, J.; Weissman, T.A.; Unni, V.K. Genetic deletion of Polo-like kinase 2 reduces alpha-synuclein serine-129 phosphorylation in presynaptic terminals but not Lewy bodies. J. Biol. Chem. 2021, 296, 100273. [CrossRef]

121. Oueslati, A. Implication of Alpha-Synuclein Phosphorylation at S129 in Synucleinopathies: What Have We Learned in the Last Decade? J. Parkinsons Dis. 2016, 6, 39-51. [CrossRef]

122. Steger, M.; Diez, F.; Dhekne, H.S.; Lis, P.; Nirujogi, R.S.; Karayel, O.; Tonelli, F.; Martinez, T.N.; Lorentzen, E.; Pfeffer, S.R.; et al Systematic proteomic analysis of LRRK2-mediated Rab GTPase phosphorylation establishes a connection to ciliogenesis. Elife 2017, 6, e31012. [CrossRef] 
123. Jeong, G.R.; Jang, E.H.; Bae, J.R.; Jun, S.; Kang, H.C.; Park, C.H.; Shin, J.H.; Yamamoto, Y.; Tanaka-Yamamoto, K.; Dawson, V.L.; et al. Dysregulated phosphorylation of Rab GTPases by LRRK2 induces neurodegeneration. Mol. Neurodegener. 2018, 13, 8. [CrossRef] [PubMed]

124. Bae, E.-J.; Kim, D.-K.; Kim, C.; Mante, M.; Adame, A.; Rockenstein, E.; Ulusoy, A.; Klinkenberg, M.; Jeong, G.R.; Bae, J.R.; et al. LRRK2 kinase regulates $\alpha$-synuclein propagation via RAB35 phosphorylation. Nat. Commun. 2018, 9, 3465. [CrossRef]

125. Bonet-Ponce, L.; Cookson, M.R. The role of Rab GTPases in the pathobiology of Parkinson' disease. Curr. Opin. Cell Biol. 2019, 59, 73-80. [CrossRef] [PubMed]

126. Sidransky, E.; Nalls, M.A.; Aasly, J.O.; Aharon-Peretz, J.; Annesi, G.; Barbosa, E.R.; Bar-Shira, A.; Berg, D.; Bras, J.; Brice, A.; et al. Multicenter analysis of glucocerebrosidase mutations in Parkinson's disease. N. Engl. J. Med. 2009, 361, 1651-1661. [CrossRef]

127. Tayebi, N.; Callahan, M.; Madike, V.; Stubblefield, B.K.; Orvisky, E.; Krasnewich, D.; Fillano, J.J.; Sidransky, E. Gaucher disease and parkinsonism: A phenotypic and genotypic characterization. Mol. Genet. Metab. 2001, 73, 313-321. [CrossRef]

128. Mitsui, J.; Mizuta, I.; Toyoda, A.; Ashida, R.; Takahashi, Y.; Goto, J.; Fukuda, Y.; Date, H.; Iwata, A.; Yamamoto, M.; et al. Mutations for Gaucher disease confer high susceptibility to Parkinson disease. Arch. Neurol. 2009, 66, 571-576. [CrossRef]

129. Cullen, V.; Sardi, S.P.; Ng, J.; Xu, Y.H.; Sun, Y.; Tomlinson, J.J.; Kolodziej, P.; Kahn, I.; Saftig, P.; Woulfe, J.; et al. Acid betaglucosidase mutants linked to Gaucher disease, Parkinson disease, and Lewy body dementia alter alpha-synuclein processing. Ann. Neurol. 2011, 69, 940-953. [CrossRef]

130. Tsuang, D.; Leverenz, J.B.; Lopez, O.L.; Hamilton, R.L.; Bennett, D.A.; Schneider, J.A.; Buchman, A.S.; Larson, E.B.; Crane, P.K.; Kaye, J.A.; et al. GBA mutations increase risk for Lewy body disease with and without Alzheimer disease pathology. Neurology 2012, 79, 1944-1950. [CrossRef] [PubMed]

131. Cilia, R.; Tunesi, S.; Marotta, G.; Cereda, E.; Siri, C.; Tesei, S.; Zecchinelli, A.L.; Canesi, M.; Mariani, C.B.; Meucci, N.; et al. Survival and dementia in GBA-associated Parkinson's disease: The mutation matters. Ann. Neurol. 2016, 80, 662-673. [CrossRef] [PubMed]

132. Neumann, J.; Bras, J.; Deas, E.; O’Sullivan, S.S.; Parkkinen, L.; Lachmann, R.H.; Li, A.; Holton, J.; Guerreiro, R.; Paudel, R.; et al. Glucocerebrosidase mutations in clinical and pathologically proven Parkinson's disease. Brain 2009, 132, 1783-1794. [CrossRef]

133. Mazzulli, J.R.; Xu, Y.H.; Sun, Y.; Knight, A.L.; McLean, P.J.; Caldwell, G.A.; Sidransky, E.; Grabowski, G.A.; Krainc, D. Gaucher disease glucocerebrosidase and $\alpha$-synuclein form a bidirectional pathogenic loop in synucleinopathies. Cell 2011, 146, 37-52. [CrossRef]

134. Kitada, T.; Asakawa, S.; Hattori, N.; Matsumine, H.; Yamamura, Y.; Minoshima, S.; Yokochi, M.; Mizuno, Y.; Shimizu, N. Mutations in the parkin gene cause autosomal recessive juvenile parkinsonism. Nature 1998, 392, 605-608. [CrossRef]

135. Bonifati, V.; Rizzu, P.; van Baren, M.J.; Schaap, O.; Breedveld, G.J.; Krieger, E.; Dekker, M.C.; Squitieri, F.; Ibanez, P.; Joosse, M.; et al. Mutations in the DJ-1 gene associated with autosomal recessive early-onset parkinsonism. Science 2003, 299, 256-259. [CrossRef]

136. Valente, E.M.; Abou-Sleiman, P.M.; Caputo, V.; Muqit, M.M.; Harvey, K.; Gispert, S.; Ali, Z.; Del Turco, D.; Bentivoglio, A.R.; Healy, D.G.; et al. Hereditary early-onset Parkinson's disease caused by mutations in PINK1. Science 2004, 304, 1158-1160. [CrossRef] [PubMed]

137. Petrucelli, L.; O’Farrell, C.; Lockhart, P.J.; Baptista, M.; Kehoe, K.; Vink, L.; Choi, P.; Wolozin, B.; Farrer, M.; Hardy, J.; et al. Parkin protects against the toxicity associated with mutant alpha-synuclein: Proteasome dysfunction selectively affects catecholaminergic neurons. Neuron 2002, 36, 1007-1019. [CrossRef]

138. Haywood, A.F.; Staveley, B.E. Parkin counteracts symptoms in a Drosophila model of Parkinson's disease. BMC Neurosci. 2004, 5, 14. [CrossRef] [PubMed]

139. Khandelwal, P.J.; Dumanis, S.B.; Feng, L.R.; Maguire-Zeiss, K.; Rebeck, G.W.; Lashuel, H.A.; Moussa, C.E.H. Parkinson-related parkin reduces $\alpha$-Synuclein phosphorylation in a gene transfer model. Mol. Neurodegener. 2010, 5, 47. [CrossRef]

140. Miyakawa, S.; Ogino, M.; Funabe, S.; Uchino, A.; Shimo, Y.; Hattori, N.; Ichinoe, M.; Mikami, T.; Saegusa, M.; Nishiyama, K.; et al. Lewy body pathology in a patient with a homozygous parkin deletion. Mov. Disord. Off. J. Mov. Disord. Soc. 2013, 28, 388-391. [CrossRef]

141. Sasaki, S.; Shirata, A.; Yamane, K.; Iwata, M. Parkin-positive autosomal recessive juvenile Parkinsonism with alpha-synucleinpositive inclusions. Neurology 2004, 63, 678-682. [CrossRef] [PubMed]

142. Farrer, M.; Chan, P.; Chen, R.; Tan, L.; Lincoln, S.; Hernandez, D.; Forno, L.; Gwinn-Hardy, K.; Petrucelli, L.; Hussey, J.; et al. Lewy bodies and parkinsonism in families with parkin mutations. Ann. Neurol. 2001, 50, 293-300. [CrossRef] [PubMed]

143. Alcalay, R.N.; Caccappolo, E.; Mejia-Santana, H.; Tang, M.X.; Rosado, L.; Orbe Reilly, M.; Ruiz, D.; Louis, E.D.; Comella, C.L.; Nance, M.A.; et al. Cognitive and motor function in long-duration PARKIN-associated Parkinson disease. JAMA Neurol. 2014, 71, 62-67. [CrossRef] [PubMed]

144. Li, Y.; Tomiyama, H.; Sato, K.; Hatano, Y.; Yoshino, H.; Atsumi, M.; Kitaguchi, M.; Sasaki, S.; Kawaguchi, S.; Miyajima, H.; et al. Clinicogenetic study of PINK1 mutations in autosomal recessive early-onset parkinsonism. Neurology 2005, 64, $1955-1957$. [CrossRef] [PubMed]

145. Tunold, J.-A.; Geut, H.; Rozemuller, J.M.A.; Henriksen, S.P.; Toft, M.; van de Berg, W.D.J.; Pihlstrøm, L. APOE and MAPT Are Associated With Dementia in Neuropathologically Confirmed Parkinson's Disease. Front. Neurol. 2021, 12, 52. [CrossRef]

146. Bras, J.; Guerreiro, R.; Darwent, L.; Parkkinen, L.; Ansorge, O.; Escott-Price, V.; Hernandez, D.G.; Nalls, M.A.; Clark, L.N.; Honig, L.S.; et al. Genetic analysis implicates APOE, SNCA and suggests lysosomal dysfunction in the etiology of dementia with Lewy bodies. Hum. Mol. Genet. 2014, 23, 6139-6146. [CrossRef] 
147. Guerreiro, R.; Ross, O.A.; Kun-Rodrigues, C.; Hernandez, D.G.; Orme, T.; Eicher, J.D.; Shepherd, C.E.; Parkkinen, L.; Darwent, L.; Heckman, M.G.; et al. Investigating the genetic architecture of dementia with Lewy bodies: A two-stage genome-wide association study. Lancet Neurol. 2018, 17, 64-74. [CrossRef]

148. Tsuang, D.; Leverenz, J.B.; Lopez, O.L.; Hamilton, R.L.; Bennett, D.A.; Schneider, J.A.; Buchman, A.S.; Larson, E.B.; Crane, P.K.; Kaye, J.A.; et al. APOE $\varepsilon 4$ increases risk for dementia in pure synucleinopathies. JAMA Neurol. 2013, 70, 223-228. [CrossRef]

149. Huang, X.; Chen, P.; Kaufer, D.I.; Troster, A.I.; Poole, C. Apolipoprotein E and dementia in Parkinson disease: A meta-analysis. Arch. Neurol. 2006, 63, 189-193. [CrossRef] [PubMed]

150. Dickson, D.W.; Heckman, M.G.; Murray, M.E.; Soto, A.I.; Walton, R.L.; Diehl, N.N.; van Gerpen, J.A.; Uitti, R.J.; Wszolek, Z.K.; Ertekin-Taner, N.; et al. APOE $\varepsilon 4$ is associated with severity of Lewy body pathology independent of Alzheimer pathology. Neurology 2018, 91, e1182-e1195. [CrossRef]

151. Tan, M.M.X.; Lawton, M.A.; Jabbari, E.; Reynolds, R.H.; Iwaki, H.; Blauwendraat, C.; Kanavou, S.; Pollard, M.I.; Hubbard, L.; Malek, N.; et al. Genome-Wide Association Studies of Cognitive and Motor Progression in Parkinson's Disease. Mov. Disord. 2021, 36, 424-433. [CrossRef]

152. Davis, A.A.; Inman, C.E.; Wargel, Z.M.; Dube, U.; Freeberg, B.M.; Galluppi, A.; Haines, J.N.; Dhavale, D.D.; Miller, R.; Choudhury, F.A.; et al. APOE genotype regulates pathology and disease progression in synucleinopathy. Sci. Transl. Med. 2020, 12, eaay3069. [CrossRef]

153. Zhao, N.; Attrebi, O.N.; Ren, Y.; Qiao, W.; Sonustun, B.; Martens, Y.A.; Meneses, A.D.; Li, F.; Shue, F.; Zheng, J.; et al. APOE4 exacerbates $\alpha$-synuclein pathology and related toxicity independent of amyloid. Sci. Transl. Med. 2020, 12. [CrossRef]

154. Pascale, E.; Di Battista, M.E.; Rubino, A.; Purcaro, C.; Valente, M.; Fattapposta, F.; Ferraguti, G.; Meco, G. Genetic Architecture of MAPT Gene Region in Parkinson Disease Subtypes. Front. Cell Neurosci. 2016, 10, 96. [CrossRef]

155. Giasson, B.I.; Forman, M.S.; Higuchi, M.; Golbe, L.I.; Graves, C.L.; Kotzbauer, P.T.; Trojanowski, J.Q.; Lee, V.M. Initiation and synergistic fibrillization of tau and alpha-synuclein. Science 2003, 300, 636-640. [CrossRef] [PubMed]

156. Seto-Salvia, N.; Clarimon, J.; Pagonabarraga, J.; Pascual-Sedano, B.; Campolongo, A.; Combarros, O.; Mateo, J.I.; Regana, D.; Martinez-Corral, M.; Marquie, M.; et al. Dementia risk in Parkinson disease: Disentangling the role of MAPT haplotypes. Arch. Neurol. 2011, 68, 359-364. [CrossRef] [PubMed]

157. Williams-Gray, C.H.; Evans, J.R.; Goris, A.; Foltynie, T.; Ban, M.; Robbins, T.W.; Brayne, C.; Kolachana, B.S.; Weinberger, D.R.; Sawcer, S.J.; et al. The distinct cognitive syndromes of Parkinson's disease: 5 year follow-up of the CamPaIGN cohort. Brain 2009, 132, 2958-2969. [CrossRef] [PubMed]

158. Goris, A.; Williams-Gray, C.H.; Clark, G.R.; Foltynie, T.; Lewis, S.J.; Brown, J.; Ban, M.; Spillantini, M.G.; Compston, A.; Burn, D.J.; et al. Tau and alpha-synuclein in susceptibility to, and dementia in, Parkinson's disease. Ann. Neurol. 2007, 62, 145-153. [CrossRef]

159. Mamah, C.E.; Lesnick, T.G.; Lincoln, S.J.; Strain, K.J.; de Andrade, M.; Bower, J.H.; Ahlskog, J.E.; Rocca, W.A.; Farrer, M.J.; Maraganore, D.M. Interaction of alpha-synuclein and tau genotypes in Parkinson's disease. Ann. Neurol. 2005, 57, 439-443. [CrossRef]

160. Botta-Orfila, T.; Ezquerra, M.; Rios, J.; Fernandez-Santiago, R.; Cervantes, S.; Samaranch, L.; Pastor, P.; Marti, M.J.; Munoz, E.; Valldeoriola, F.; et al. Lack of interaction of SNCA and MAPT genotypes in Parkinson's disease. Eur. J. Neurol. 2011, 18, e32. [CrossRef]

161. Elbaz, A.; Ross, O.A.; Ioannidis, J.P.; Soto-Ortolaza, A.I.; Moisan, F.; Aasly, J.; Annesi, G.; Bozi, M.; Brighina, L.; Chartier-Harlin, M.C.; et al. Independent and joint effects of the MAPT and SNCA genes in Parkinson disease. Ann. Neurol. 2011, 69, 778-792. [CrossRef]

162. Biernacka, J.M.; Armasu, S.M.; Cunningham, J.M.; Ahlskog, J.E.; Chung, S.J.; Maraganore, D.M. Do interactions between SNCA, MAPT, and LRRK2 genes contribute to Parkinson's disease susceptibility? Parkinsonism Relat. Disord. 2011, 17, 730-736. [CrossRef]

163. Dudbridge, F. Power and predictive accuracy of polygenic risk scores. PLoS Genet. 2013, 9, e1003348. [CrossRef]

164. Foo, J.N.; Chew, E.G.Y.; Chung, S.J.; Peng, R.; Blauwendraat, C.; Nalls, M.A.; Mok, K.Y.; Satake, W.; Toda, T.; Chao, Y.; et al. Identification of Risk Loci for Parkinson Disease in Asians and Comparison of Risk Between Asians and Europeans: A GenomeWide Association Study. JAMA Neurol. 2020, 77, 746-754. [CrossRef]

165. Paul, K.C.; Schulz, J.; Bronstein, J.M.; Lill, C.M.; Ritz, B.R. Association of Polygenic Risk Score With Cognitive Decline and Motor Progression in Parkinson Disease. JAMA Neurol. 2018, 75, 360. [CrossRef] [PubMed]

166. Braak, H.; Del Tredici, K.; Rub, U.; de Vos, R.A.; Jansen Steur, E.N.; Braak, E. Staging of brain pathology related to sporadic Parkinson's disease. Neurobiol. Aging 2003, 24, 197-211. [CrossRef]

167. Braak, H.; Ghebremedhin, E.; Rub, U.; Bratzke, H.; Del Tredici, K. Stages in the development of Parkinson's disease-related pathology. Cell Tissue Res. 2004, 318, 121-134. [CrossRef]

168. Beach, T.G.; Adler, C.H.; Lue, L.; Sue, L.I.; Bachalakuri, J.; Henry-Watson, J.; Sasse, J.; Boyer, S.; Shirohi, S.; Brooks, R.; et al. Unified staging system for Lewy body disorders: Correlation with nigrostriatal degeneration, cognitive impairment and motor dysfunction. Acta Neuropathol. 2009, 117, 613-634. [CrossRef]

169. Rey, N.L.; Wesson, D.W.; Brundin, P. The olfactory bulb as the entry site for prion-like propagation in neurodegenerative diseases. Neurobiol. Dis. 2018, 109, 226-248. [CrossRef]

170. Borghammer, P.; Van Den Berge, N. Brain-First versus Gut-First Parkinson's Disease: A Hypothesis. J. Parkinsons Dis. 2019, 9 , S281-S295. [CrossRef] [PubMed] 
171. Giguère, N.; Burke Nanni, S.; Trudeau, L.-E. On Cell Loss and Selective Vulnerability of Neuronal Populations in Parkinson's Disease. Front. Neurol. 2018, 9, 455. [CrossRef] [PubMed]

172. Double, K.L. Neuronal vulnerability in Parkinson's disease. Parkinsonism Relat. Disord. 2012, 18, S52-S54. [CrossRef]

173. Bloch, A.; Probst, A.; Bissig, H.; Adams, H.; Tolnay, M. Alpha-synuclein pathology of the spinal and peripheral autonomic nervous system in neurologically unimpaired elderly subjects. Neuropathol. Appl. Neurobiol. 2006, 32, 284-295. [CrossRef]

174. Borghammer, P. The $\alpha$-Synuclein Origin and Connectome Model (SOC Model) of Parkinson's Disease: Explaining Motor Asymmetry, Non-Motor Phenotypes, and Cognitive Decline. J. Parkinsons Dis. 2021, 11, 455-474. [CrossRef] [PubMed]

175. Aarsland, D.; Perry, R.; Brown, A.; Larsen, J.P.; Ballard, C. Neuropathology of dementia in Parkinson's disease: A prospective, community-based study. Ann. Neurol. 2005, 58, 773-776. [CrossRef]

176. Ballard, C.; Ziabreva, I.; Perry, R.; Larsen, J.P.; O’Brien, J.; McKeith, I.; Perry, E.; Aarsland, D. Differences in neuropathologic characteristics across the Lewy body dementia spectrum. Neurology 2006, 67, 1931-1934. [CrossRef]

177. Hernandez, S.M.; Tikhonova, E.B.; Karamyshev, A.L. Protein-Protein Interactions in Alpha-Synuclein Biogenesis: New Potential Targets in Parkinson's Disease. Front. Aging Neurosci. 2020, 12, 72. [CrossRef]

178. Auluck, P.K.; Chan, H.Y.; Trojanowski, J.Q.; Lee, V.M.; Bonini, N.M. Chaperone suppression of alpha-synuclein toxicity in a Drosophila model for Parkinson's disease. Science 2002, 295, 865-868. [CrossRef]

179. Sot, B.; Rubio-Muñoz, A.; Leal-Quintero, A.; Martínez-Sabando, J.; Marcilla, M.; Roodveldt, C.; Valpuesta, J.M. The chaperonin CCT inhibits assembly of $\alpha$-synuclein amyloid fibrils by a specific, conformation-dependent interaction. Sci. Rep. 2017, 7, 40859. [CrossRef] [PubMed]

180. Giasson, B.I.; Duda, J.E.; Murray, I.V.J.; Chen, Q.; Souza, J.M.; Hurtig, H.I.; Ischiropoulos, H.; Trojanowski, J.Q.; Lee, V.M.-Y. Oxidative Damage Linked to Neurodegeneration by Selective alpha-Synuclein Nitration in Synucleinopathy Lesions. Science 2000, 290, 985-989. [CrossRef]

181. Shimura, H.; Schlossmacher, M.G.; Hattori, N.; Frosch, M.P.; Trockenbacher, A.; Schneider, R.; Mizuno, Y.; Kosik, K.S.; Selkoe, D.J Ubiquitination of a New Form of alpha-Synuclein by Parkin from Human Brain: Implications for Parkinson's Disease. Science 2001, 293, 263-269. [CrossRef]

182. Fujiwara, H.; Hasegawa, M.; Dohmae, N.; Kawashima, A.; Masliah, E.; Goldberg, M.S.; Shen, J.; Takio, K.; Iwatsubo, T. $\alpha$-Synuclein is phosphorylated in synucleinopathy lesions. Nat. Cell Biol. 2002, 4, 160-164. [CrossRef]

183. Li, W.; West, N.; Colla, E.; Pletnikova, O.; Troncoso, J.C.; Marsh, L.; Dawson, T.M.; Jäkälä, P.; Hartmann, T.; Price, D.L. Aggregation promoting C-terminal truncation of $\alpha$-synuclein is a normal cellular process and is enhanced by the familial Parkinson's disease-linked mutations. Proc. Natl. Acad. Sci. USA 2005, 102, 2162-2167. [CrossRef] [PubMed]

184. Dorval, V.; Fraser, P.E. Small ubiquitin-like modifier (SUMO) modification of natively unfolded proteins tau and alpha-synuclein. J. Biol. Chem. 2006, 281, 9919-9924. [CrossRef] [PubMed]

185. Anderson, J.P.; Walker, D.E.; Goldstein, J.M.; de Laat, R.; Banducci, K.; Caccavello, R.J.; Barbour, R.; Huang, J.; Kling, K.; Lee, M.; et al. Phosphorylation of Ser-129 Is the Dominant Pathological Modification of a-Synuclein in Familial and Sporadic Lewy Body Disease. J. Biol. Chem. 2006, 281, 29739-29752. [CrossRef] [PubMed]

186. Walker, D.G.; Lue, L.-F.; Adler, C.H.; Shill, H.A.; Caviness, J.N.; Sabbagh, M.N.; Akiyama, H.; Serrano, G.E.; Sue, L.I.; Beach, T.G. Changes in properties of serine 129 phosphorylated $\alpha$-synuclein with progression of Lewy-type histopathology in human brains. Exp. Neurol. 2013, 240, 190-204. [CrossRef] [PubMed]

187. McFarland, M.A.; Ellis, C.E.; Markey, S.P.; Nussbaum, R.L. Proteomics analysis identifies phosphorylation-dependent alphasynuclein protein interactions. Mol. Cell Proteom. 2008, 7, 2123-2137. [CrossRef]

188. Leverenz, J.B.; Umar, I.; Wang, Q.; Montine, T.J.; McMillan, P.J.; Tsuang, D.W.; Jin, J.; Pan, C.; Shin, J.; Zhu, D.; et al. Proteomic identification of novel proteins in cortical lewy bodies. Brain Pathol. 2007, 17, 139-145. [CrossRef] [PubMed]

189. Gorbatyuk, O.S.; Li, S.; Sullivan, L.F.; Chen, W.; Kondrikova, G.; Manfredsson, F.P.; Mandel, R.J.; Muzyczka, N. The phosphorylation state of Ser-129 in human alpha-synuclein determines neurodegeneration in a rat model of Parkinson disease. Proc. Natl. Acad. Sci. USA 2008, 105, 763-768. [CrossRef]

190. Febbraro, F.; Sahin, G.; Farran, A.; Soares, S.; Jensen, P.H.; Kirik, D.; Romero-Ramos, M. Ser129D mutant alpha-synuclein induces earlier motor dysfunction while S129A results in distinctive pathology in a rat model of Parkinson's disease. Neurobiol. Dis. 2013, 56, 47-58. [CrossRef]

191. Lee, H.J.; Suk, J.E.; Bae, E.J.; Lee, J.H.; Paik, S.R.; Lee, S.J. Assembly-dependent endocytosis and clearance of extracellular alpha-synuclein. Int. J. Biochem. Cell Biol. 2008, 40, 1835-1849. [CrossRef]

192. Lee, H.J.; Suk, J.E.; Bae, E.J.; Lee, S.J. Clearance and deposition of extracellular alpha-synuclein aggregates in microglia. Biochem. Biophys. Res. Commun. 2008, 372, 423-428. [CrossRef]

193. Giasson, B.I.; Lee, V.M.Y. Are Ubiquitination Pathways Central to Parkinson's Disease? Cell 2003, 114, 1-8. [CrossRef]

194. Tofaris, G.K.; Layfield, R.; Spillantini, M.G. Alpha-synuclein metabolism and aggregation is linked to ubiquitin-independent degradation by the proteasome. FEBS Lett. 2001, 509, 22-26. [CrossRef]

195. Vogiatzi, T.; Xilouri, M.; Vekrellis, K.; Stefanis, L. Wild Type $\alpha$-Synuclein Is Degraded by Chaperone-mediated Autophagy and Macroautophagy in Neuronal Cells. J. Biol. Chem. 2008, 283, 23542-23556. [CrossRef]

196. Lee, V.M.; Giasson, B.I.; Trojanowski, J.Q. More than just two peas in a pod: Common amyloidogenic properties of tau and alpha-synuclein in neurodegenerative diseases. Trends Neurosci. 2004, 27, 129-134. [CrossRef] 
197. Badiola, N.; De Oliveira, R.M.; Herrera, F.; Guardia-Laguarta, C.; Gonçalves, S.A.; Pera, M.; Suárez-Calvet, M.; Clarimon, J.; Outeiro, T.F.; Lleó, A. Tau Enhances $\alpha$-Synuclein Aggregation and Toxicity in Cellular Models of Synucleinopathy. PLoS ONE 2011, 6, e26609. [CrossRef] [PubMed]

198. Masliah, E.; Rockenstein, E.; Veinbergs, I.; Sagara, Y.; Mallory, M.; Hashimoto, M.; Mucke, L. $\beta$-Amyloid peptides enhance $\alpha$-synuclein accumulation and neuronal deficits in a transgenic mouse model linking Alzheimer's disease and Parkinson's disease. Proc. Natl. Acad. Sci. USA 2001, 98, 12245-12250. [CrossRef]

199. Clinton, L.K.; Blurton-Jones, M.; Myczek, K.; Trojanowski, J.Q.; LaFerla, F.M. Synergistic Interactions between Abeta, tau, and alpha-synuclein: Acceleration of neuropathology and cognitive decline. J. Neurosci. 2010, 30, 7281-7289. [CrossRef] [PubMed]

200. Smith, C.; Malek, N.; Grosset, K.; Cullen, B.; Gentleman, S.; Grosset, D.G. Neuropathology of dementia in patients with Parkinson's disease: A systematic review of autopsy studies. J. Neurol. Neurosurg. Psychiatry 2019, 90, 1234-1243. [CrossRef]

201. Irwin, D.J.; Lee, V.M.Y.; Trojanowski, J.Q. Parkinson's disease dementia: Convergence of $\alpha$-synuclein, tau and amyloid- $\beta$ pathologies. Nat. Rev. Neurosci. 2013, 14, 626-636. [CrossRef] [PubMed]

202. Gomperts, S.N.; Locascio, J.J.; Makaretz, S.J.; Schultz, A.; Caso, C.; Vasdev, N.; Sperling, R.; Growdon, J.H.; Dickerson, B.C.; Johnson, K. Tau Positron Emission Tomographic Imaging in the Lewy Body Diseases. JAMA Neurol. 2016, 73, $1334-1341$. [CrossRef] [PubMed]

203. Bassil, F.; Meymand, E.S.; Brown, H.J.; Xu, H.; Cox, T.O.; Pattabhiraman, S.; Maghames, C.M.; Wu, Q.; Zhang, B.; Trojanowski, J.Q.; et al. $\alpha$-Synuclein modulates tau spreading in mouse brains. J. Exp. Med. 2021, 218, e20192193. [CrossRef]

204. Hong, Z.; Shi, M.; Chung, K.A.; Quinn, J.F.; Peskind, E.R.; Galasko, D.; Jankovic, J.; Zabetian, C.P.; Leverenz, J.B.; Baird, G.; et al. DJ-1 and alpha-synuclein in human cerebrospinal fluid as biomarkers of Parkinson's disease. Brain 2010, 133, 713-726. [CrossRef] [PubMed]

205. Mollenhauer, B.; Cullen, V.; Kahn, I.; Krastins, B.; Outeiro, T.F.; Pepivani, I.; Ng, J.; Schulz-Schaeffer, W.; Kretzschmar, H.A.; McLean, P.J.; et al. Direct quantification of CSF alpha-synuclein by ELISA and first cross-sectional study in patients with neurodegeneration. Exp. Neurol. 2008, 213, 315-325. [CrossRef] [PubMed]

206. Mollenhauer, B.; Locascio, J.J.; Schulz-Schaeffer, W.; Sixel-Döring, F.; Trenkwalder, C.; Schlossmacher, M.G. $\alpha$-Synuclein and tau concentrations in cerebrospinal fluid of patients presenting with parkinsonism: A cohort study. Lancet Neurol. 2011, 10, 230-240. [CrossRef]

207. Tokuda, T.; Salem, S.A.; Allsop, D.; Mizuno, T.; Nakagawa, M.; Qureshi, M.M.; Locascio, J.J.; Schlossmacher, M.G.; El-Agnaf, O.M. Decreased alpha-synuclein in cerebrospinal fluid of aged individuals and subjects with Parkinson's disease. Biochem. Biophys. Res. Commun. 2006, 349, 162-166. [CrossRef]

208. Wennström, M.; Surova, Y.; Hall, S.; Nilsson, C.; Minthon, L.; Boström, F.; Hansson, O.; Nielsen, H.M. Low CSF levels of both $\alpha$-synuclein and the $\alpha$-synuclein cleaving enzyme neurosin in patients with synucleinopathy. PLoS ONE 2013, 8, e53250. [CrossRef]

209. Stewart, T.; Liu, C.; Ginghina, C.; Cain, K.C.; Auinger, P.; Cholerton, B.; Shi, M.; Zhang, J. Cerebrospinal fluid $\alpha$-synuclein predicts cognitive decline in Parkinson disease progression in the DATATOP cohort. Am. J. Pathol. 2014, 184, 966-975. [CrossRef]

210. Hall, S.; Surova, Y.; Öhrfelt, A.; Zetterberg, H.; Lindqvist, D.; Hansson, O. CSF biomarkers and clinical progression of Parkinson disease. Neurology 2015, 84, 57-63. [CrossRef]

211. Goldman, J.G.; Andrews, H.; Amara, A.; Naito, A.; Alcalay, R.N.; Shaw, L.M.; Taylor, P.; Xie, T.; Tuite, P.; Henchcliffe, C.; et al. Cerebrospinal fluid, plasma, and saliva in the BioFIND study: Relationships among biomarkers and Parkinson's disease Features. Mov. Disord. 2018, 33, 282-288. [CrossRef] [PubMed]

212. Lin, C.-H.; Yang, S.-Y.; Horng, H.-E.; Yang, C.-C.; Chieh, J.-J.; Chen, H.-H.; Liu, B.-H.; Chiu, M.-J. Plasma $\alpha$-synuclein predicts cognitive decline in Parkinson's disease. J. Neurol. Neurosurg. Psychiatry 2017, 88, 818-824. [CrossRef] [PubMed]

213. Chang, C.-W.; Yang, S.-Y.; Yang, C.-C.; Chang, C.-W.; Wu, Y.-R. Plasma and Serum Alpha-Synuclein as a Biomarker of Diagnosis in Patients with Parkinson's Disease. Front. Neurol. 2020, 10, 1388. [CrossRef]

214. Maass, F.; Rikker, S.; Dambeck, V.; Warth, C.; Tatenhorst, L.; Csoti, I.; Schmitz, M.; Zerr, I.; Leha, A.; Bähr, M.; et al. Increased alpha-synuclein tear fluid levels in patients with Parkinson's disease. Sci. Rep. 2020, 10, 8507. [CrossRef]

215. Wang, Z.; Becker, K.; Donadio, V.; Siedlak, S.; Yuan, J.; Rezaee, M.; Incensi, A.; Kuzkina, A.; Orru, C.D.; Tatsuoka, C.; et al. Skin alpha-Synuclein Aggregation Seeding Activity as a Novel Biomarker for Parkinson Disease. JAMA Neurol. 2021, 78, 30-40. [CrossRef] [PubMed]

216. Donadio, V.; Incensi, A.; El-Agnaf, O.; Rizzo, G.; Vaikath, N.; Del Sorbo, F.; Scaglione, C.; Capellari, S.; Elia, A.; Stanzani Maserati, M.; et al. Skin $\alpha$-synuclein deposits differ in clinical variants of synucleinopathy: An in vivo study. Sci. Rep. 2018, 8, 14246. [CrossRef]

217. Mikolaenko, I.; Pletnikova, O.; Kawas, C.H.; O’Brien, R.; Resnick, S.M.; Crain, B.; Troncoso, J.C. Alpha-synuclein lesions in normal aging, Parkinson disease, and Alzheimer disease: Evidence from the Baltimore Longitudinal Study of Aging (BLSA). J. Neuropathol. Exp. Neurol. 2005, 64, 156-162. [CrossRef] [PubMed]

218. Hughes, A.J.; Daniel, S.E.; Blankson, S.; Lees, A.J. A clinicopathologic study of 100 cases of Parkinson's disease. Arch. Neurol. 1993, 50, 140-148. [CrossRef]

219. Sabbagh, M.N.; Adler, C.H.; Lahti, T.J.; Connor, D.J.; Vedders, L.; Peterson, L.K.; Caviness, J.N.; Shill, H.A.; Sue, L.I.; Ziabreva, I. Parkinson's disease with dementia: Comparing patients with and without Alzheimer pathology. Alzheimer Dis. Assoc. Disord. 2009, 23, 295. [CrossRef] 
220. Lin, C.-H.; Wu, R.-M. Biomarkers of cognitive decline in Parkinson's disease. Parkinsonism Relat. Disord. 2015, 21, 431-443. [CrossRef]

221. Jellinger, K.; Seppi, K.; Wenning, G.; Poewe, W. Impact of coexistent Alzheimer pathology on the natural history of Parkinson's disease. J. Neural Transm. 2002, 109, 329-339. [CrossRef] [PubMed]

222. Yu, S.-Y.; Zuo, L.-J.; Wang, F.; Chen, Z.-J.; Hu, Y.; Wang, Y.-J.; Wang, X.-M.; Zhang, W. Potential biomarkers relating pathological proteins, neuroinflammatory factors and free radicals in PD patients with cognitive impairment: A cross-sectional study. BMC Neurol. 2014, 14, 113. [CrossRef]

223. Liu, C.; Cholerton, B.; Shi, M.; Ginghina, C.; Cain, K.C.; Auinger, P.; Zhang, J. The Parkinson Study Group DATATOP Investigators. CSF tau and tau/A $\beta 42$ predict cognitive decline in Parkinson's disease. Parkinsonism Relat. Disord. 2015, 21, 271-276. [CrossRef] [PubMed]

224. Han, L.; Tang, Y.; Bai, X.; Liang, X.; Fan, Y.; Shen, Y.; Huang, F.; Wang, J. Association of the serum microRNA-29 family with cognitive impairment in Parkinson's disease. Aging (Albany NY) 2020, 12, 13518. [CrossRef]

225. Yang, T.T.; Liu, C.G.; Gao, S.C.; Zhang, Y.; Wang, P.C. The serum exosome derived MicroRNA- 135a, - 193b, and-384 were potential Alzheimer's disease biomarkers. Biomed. Environ. Sci. 2018, 31, 87-96.

226. Zhao, L.; Wang, Z. MicroRNAs: Game changers in the regulation of $\alpha$-synuclein in Parkinson's disease. Parkinsons Dis. 2019, 2019, 1743183. [CrossRef] [PubMed]

227. Hernandez-Rapp, J.; Rainone, S.; Hébert, S.S. MicroRNAs underlying memory deficits in neurodegenerative disorders. Prog. Neuro-Psychopharmacol. Biol. Psychiatry 2017, 73, 79-86. [CrossRef]

228. Kanagaraj, N.; Beiping, H.; Dheen, S.; Tay, S. Downregulation of miR-124 in MPTP-treated mouse model of Parkinson's disease and MPP iodide-treated MN9D cells modulates the expression of the calpain/cdk5 pathway proteins. Neuroscience 2014, 272, 167-179. [CrossRef]

229. Wang, H.; Ye, Y.; Zhu, Z.; Mo, L.; Lin, C.; Wang, Q.; Wang, H.; Gong, X.; He, X.; Lu, G. MiR-124 Regulates Apoptosis and Autophagy Process in MPTP Model of P arkinson's Disease by Targeting to B im. Brain Pathol. 2016, 26, 167-176. [CrossRef]

230. Barbagallo, C.; Mostile, G.; Baglieri, G.; Giunta, F.; Luca, A.; Raciti, L.; Zappia, M.; Purrello, M.; Ragusa, M.; Nicoletti, A. Specific signatures of serum miRNAs as potential biomarkers to discriminate clinically similar neurodegenerative and vascular-related diseases. Cell. Mol. Neurobiol. 2020, 40, 531-546. [CrossRef]

231. Dos Santos, M.C.T.; Barreto-Sanz, M.A.; Correia, B.R.S.; Bell, R.; Widnall, C.; Perez, L.T.; Berteau, C.; Schulte, C.; Scheller, D.; Berg, D. miRNA-based signatures in cerebrospinal fluid as potential diagnostic tools for early stage Parkinson's disease. Oncotarget 2018, 9, 17455. [CrossRef] [PubMed]

232. Gui, Y.; Liu, H.; Zhang, L.; Lv, W.; Hu, X. Altered microRNA profiles in cerebrospinal fluid exosome in Parkinson disease and Alzheimer disease. Oncotarget 2015, 6, 37043. [CrossRef] [PubMed]

233. Rajgor, D. Macro roles for microRNAs in neurodegenerative diseases. Non-Coding RNA Res. 2018, 3, 154-159. [CrossRef]

234. Sonntag, K.-C. MicroRNAs and deregulated gene expression networks in neurodegeneration. Brain Res. 2010, $1338,48-57$. [CrossRef] [PubMed]

235. Lau, P.; Bossers, K.; Janky, R.S.; Salta, E.; Frigerio, C.S.; Barbash, S.; Rothman, R.; Sierksma, A.S.; Thathiah, A.; Greenberg, D. Alteration of the micro RNA network during the progression of Alzheimer's disease. EMBO Mol. Med. 2013, 5, 1613-1634. [CrossRef]

236. Doxakis, E. Post-transcriptional regulation of $\alpha$-synuclein expression by mir-7 and mir-153. J. Biol. Chem. 2010, 285, 12726-12734. [CrossRef] [PubMed]

237. Liang, C.; Zhu, H.; Xu, Y.; Huang, L.; Ma, C.; Deng, W.; Liu, Y.; Qin, C. MicroRNA-153 negatively regulates the expression of amyloid precursor protein and amyloid precursor-like protein 2. Brain Res. 2012, 1455, 103-113. [CrossRef]

238. Lee, J.G.; Takahama, S.; Zhang, G.; Tomarev, S.I.; Ye, Y. Unconventional secretion of misfolded proteins promotes adaptation to proteasome dysfunction in mammalian cells. Nat. Cell Biol. 2016, 18, 765-776. [CrossRef]

239. Kalluri, R.; LeBleu, V.S. The biology, function, and biomedical applications of exosomes. Science 2020, 367, 6748. [CrossRef]

240. Fiandaca, M.S.; Kapogiannis, D.; Mapstone, M.; Boxer, A.; Eitan, E.; Schwartz, J.B.; Abner, E.L.; Petersen, R.C.; Federoff, H.J.; Miller, B.L.; et al. Identification of preclinical Alzheimer's disease by a profile of pathogenic proteins in neurally derived blood exosomes: A case-control study. Alzheimers Dement. 2015, 11, 600-607.e1. [CrossRef]

241. Serpente, M.; Fenoglio, C.; D’Anca, M.; Arcaro, M.; Sorrentino, F.; Visconte, C.; Arighi, A.; Fumagalli, G.G.; Porretti, L.; Cattaneo, A.; et al. MiRNA Profiling in Plasma Neural-Derived Small Extracellular Vesicles from Patients with Alzheimer's Disease. Cells 2020, 9, 1443. [CrossRef]

242. Stuendl, A.; Kunadt, M.; Kruse, N.; Bartels, C.; Moebius, W.; Danzer, K.M.; Mollenhauer, B.; Schneider, A. Induction of $\alpha$-synuclein aggregate formation by CSF exosomes from patients with Parkinson's disease and dementia with Lewy bodies. Brain 2015, 139, 481-494. [CrossRef]

243. Jiang, C.; Hopfner, F.; Katsikoudi, A.; Hein, R.; Catli, C.; Evetts, S.; Huang, Y.; Wang, H.; Ryder, J.W.; Kuhlenbaeumer, G.; et al. Serum neuronal exosomes predict and differentiate Parkinson's disease from atypical parkinsonism. J. Neurol. Neurosurg. Psychiatry 2020, 91, 720-729. [CrossRef]

244. Chung, C.-C.; Chan, L.; Chen, J.-H.; Bamodu, O.A.; Hong, C.-T. Neurofilament light chain level in plasma extracellular vesicles and Parkinson's disease. Ther. Adv. Neurol. Disord. 2020, 13, 1756286420975917. [CrossRef] [PubMed] 
245. Chou, S.-Y.; Chan, L.; Chung, C.-C.; Chiu, J.-Y.; Hsieh, Y.-C.; Hong, C.-T. Altered insulin receptor substrate 1 phosphorylation in blood neuron-derived extracellular vesicles from patients with Parkinson's disease. Front. Cell Dev. Biol. 2020, 8, 1490. [CrossRef] [PubMed]

246. Chung, C.-C.; Chan, L.; Chen, J.-H.; Hung, Y.-C.; Hong, C.-T. Plasma Extracellular Vesicle $\alpha$-Synuclein Level in Patients with Parkinson's Disease. Biomolecules 2021, 11, 744. [CrossRef] [PubMed]

247. Shi, M.; Huber, B.R.; Zhang, J. Biomarkers for cognitive impairment in Parkinson disease. Brain Pathol. 2010, $20,660-671$. [CrossRef] [PubMed]

248. Emmanouilidou, E.; Melachroinou, K.; Roumeliotis, T.; Garbis, S.D.; Ntzouni, M.; Margaritis, L.H.; Stefanis, L.; Vekrellis, K. Cell-Produced $\alpha$-Synuclein Is Secreted in a Calcium-Dependent Manner by Exosomes and Impacts Neuronal Survival. J. Neurosci. 2010, 30, 6838-6851. [CrossRef]

249. Alvarez-Erviti, L.; Seow, Y.; Schapira, A.H.; Gardiner, C.; Sargent, I.L.; Wood, M.J.A.; Cooper, J.M. Lysosomal dysfunction increases exosome-mediated alpha-synuclein release and transmission. Neurobiol. Dis. 2011, 42, 360-367. [CrossRef] 